\title{
RITUAL PIRACY \\ OR CREOLIZATION WITH AN ATTITUDE
}

\begin{abstract}
It is a view that implicitly understands that folding of the underworld of the conquering society into the culture of the conquered not as an organic synthesis or "syncretism" of the three great streams of New World history - African, Christian, and Indian - but as a chamber of mirrors reflecting each stream's perception of the other ... This chamber of mirrors was, from the colonizer's point of view, a chamber conflating sorcery with sedition, if not in reality at least as a metaphor. (Taussig 1987:218)
\end{abstract}

Most of the scholarship in anthropology, linguistics, and literary criticism concurs in drawing on creolization as one of the signifiers to speak broadly of cultural transformation. ${ }^{1}$ But the nature of this transformation, its agents, motives, and products are by no means agreed upon. What historians, sociocultural anthropologists, linguists, and folklorists have circumscribed as the study of creole societies and creolization processes has resulted in far from a monolithic view of the past - the heated debates around An Anthropological Approach to the Afro-American Past (Mintz \& Price 1976) being just one instance.

1. I wish to thank Roger Abrahams for his inspiring lifetime work on various forms of creolization and more recently on mimesis. Initial thoughts of my argument were presented at "Rogerfest," a symposium Voice/Over dedicated to his lifetime achievements in folklore at the University of Pennsylvania in 2002; my appreciation goes also to the discussants, David Samper and Soli Otero. For their keen observations and suggestions at different stages of this work, I owe my special gratitude to Roger Abrahams, Jorge Duany, Michael Taussig, Georges Fouron, Richard Price, Paul Garrett, and the anonymous reviewers. For examples of scholarship on creolization and cultural transformation see Balutansky \& Sourieau 1998, Chaudenson 2001, Shepherd \& Richards 2002, Fernández Olmos \& Paravisini-Gebert 2003.

New West Indian Guide / Nieuwe West-Indische Gids vol. 79 no. 3 \& 4 (2005):175-218 

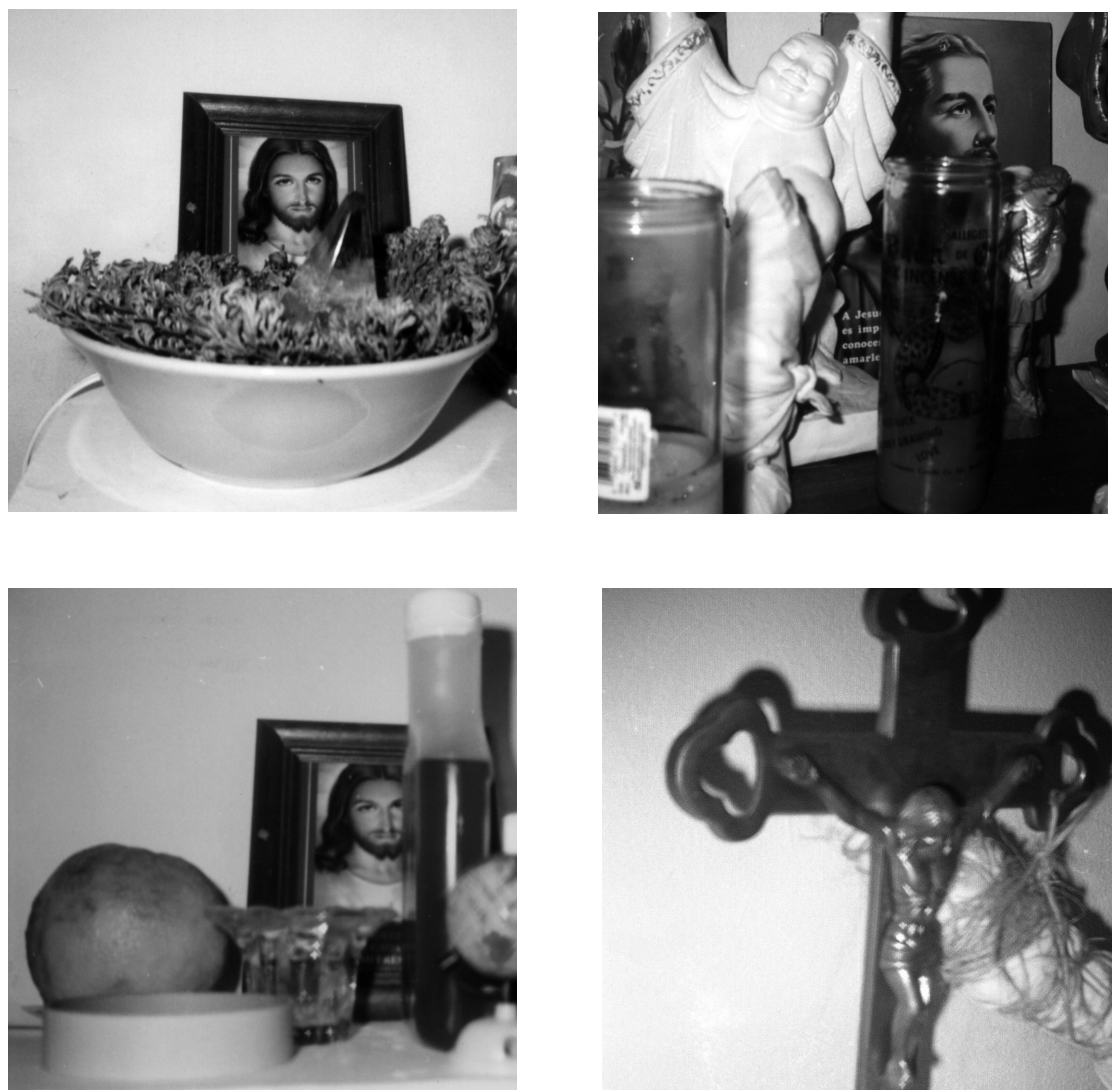

In the altar-room of a Puerto Rican self-defined bruja (witch-healer) I see a profusion of Catholic saints, Afro-Caribbean deities, a Buddha, and Amerindian spirits standing in front of the chromolithograph of a blond Jesus. Also, hanging from a large bronze cross, there is a small packet, a magic work that has been left there to be empowered by it. Could the same cross that once persecuted brujos be now empowering their magic works?

Note: Unless specified otherwise, all ethnographic references to Puerto Rican brujos are based on my eighteenth-month fieldwork in 1995-96, which appeared first in my dissertation (Romberg 1998), and then in Romberg (2003c). Conscious that the negative stereotypes of brujería (witchcraft, here translated as witch-healing) stem from a long history of persecution (paralleling that of European witchcraft), brujos today deliberately call themselves, among insiders, "brujos" and what they do "brujería" to index not only their ability to heal and solve spiritual problems, but also their pride - even arrogance - in their trade, a far cry from the dread and shame of the past. 


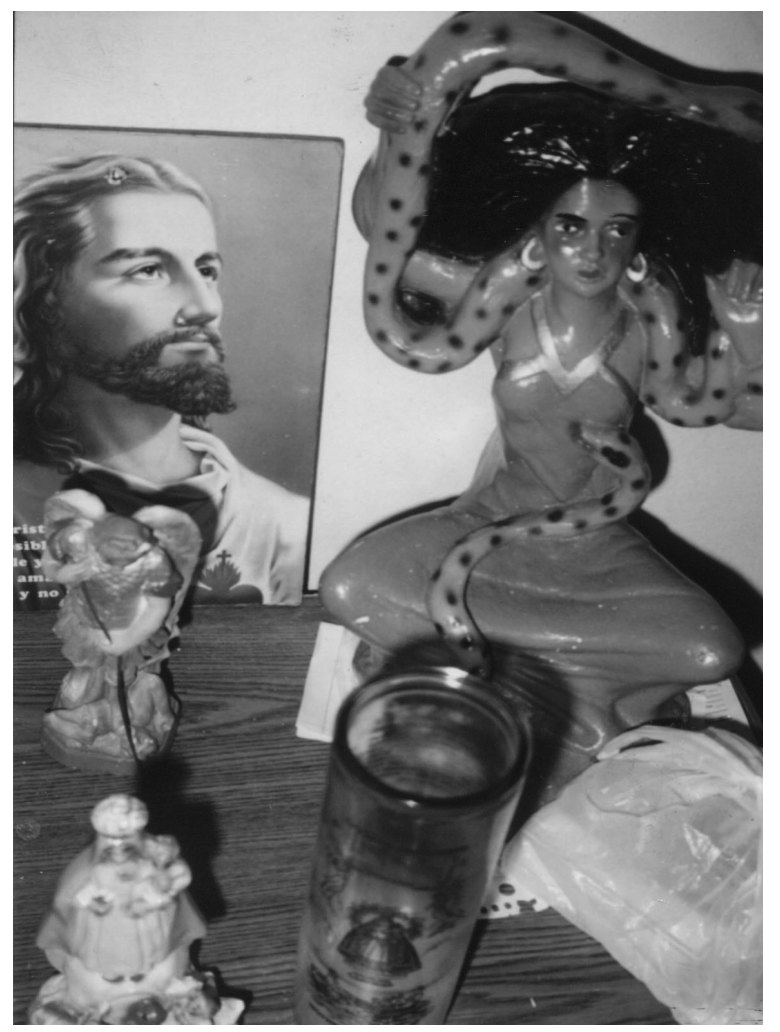

Whether creolization was the result of New World "inter-African syncretism" - characterized as a process of "discovery" by the Saramaka Maroons studied by Richard Price (2001, forthcoming); of the continuity of African traditions in the New World by ethnically differentiated homogeneous enslaved African groups; or the pragmatic adaptation of heterogeneous groups of enslaved and freed African-born and creole groups in confronting European colonialism and exploitation, its study is very much entangled in controversial portrayals of the past. Following Price (2001, forthcoming), this entanglement appears to be often the result of the repositioning of historical-specific analysis within comparative cross-cultural projects (some of which respond to programmatic quests for a politically engaged scholarship that follows a particular local politics of race); or, more broadly, the conclusion that "that" event is inseparable from "this" memory of that event (Scott 1991). In sum, to unknot creolization as process, as ideology, and as theory, is a challenging task.

Not only in academic circles, but also within native contexts, "creole," things creole, and "creolization" are contested terrains that reflect the conflicting sociopolitical, local meanings they have gathered throughout their 
trajectories in Caribbean history. ${ }^{2}$ Over the span of almost four centuries, "creolization" has been engaged - from colonization to nation-building and lately in postcolonial discourse - in myriad conflicting social projects. In this trajectory it has been deployed alternatively (in social, political, literary, and entrepreneurial discursive and non-discursive practices) to serve racist, developmental, modernist, and conciliatory politics. Originally an emic term that had indexed racial and linguistic differences during colonization, "creole" was later transmuted in postindependence societies into the essence of their national ideology, also acquiring an aesthetic and moral value - within the postcolonial creolité artistic movement, for example - that was to transcend the Caribbean (Bernabé et al. 1989), which reminds us that cultural traditions "are not only authored; they are authorized. They not only make intelligible; they make legitimate" (Scott 1991:279).

But one thing unites scholarly and native discourses of creolization: whether "creole" is used as a modifier of language, ethnicity, nation, or culture, it essentially implies some form of "mixture" (Szwed 2003). Mixture, however, even in its most sophisticated rendition, reflects only the materialization (or the iconic end product) of a convoluted and painful process, involving unequally situated groups interacting in specific geopolitical contexts. Rather than being the essence of creolization, mixture is its problematic referent, as evidenced in ongoing controversies about the timing, components, and outcomes of these mixtures with regard to whether one is referring to early or later nineteenth-century forms of creolization under English, Dutch, French, or Spanish colonial enterprises, whether their loci were plantation or urban slave societies. I thus limit my discussion to mostly late-nineteenth-century creolization processes centered on urban slave and highland-peasant-Maroon societies under Spanish colonial rule - societies that were overall intensely linked to European settlers and their mores. Initial (first- and second-generation) creolization processes, of the kind described by the Prices in Suriname and Trouillot in Haiti, for example, took place in socioeconomic and cultural circumstances very different from those I describe here, with much less input from Europeans and their cultures. Thus, the kind of "creolization with an attitude" I pursue here is limited to the historically specific circumstances of nineteenth-century Hispanic and Luso-tropic societies.

Indeed, this particular set of historical circumstances, more than earlier ones elsewhere within the Caribbean, shows a persistent double bind resulting from the high value placed on the "purity" of metropolitan cultures and the actual "mixing" of uprooted people and cultures that were relocated in the colonies. Thus, this examination of creolization asks for an in-depth (and possibly retrospective) phenomenological examination of the micropoetics

2. For recent sources that review the etymological origins of criollo/creole, see Chaudenson (2001) and Allen (2002). 
and politics of cultural difference, as it was informed by the terror/fascination it produced (Taussig 1987, Young 1995) - not of mixtures. In other words, "mixture" - or "dialogue among difference" in its various versions, the more recent trope within globalization theories (Hannerz 1987, 1990, 1996) - implies an equity among social groups and their religious practices that does not seem to have ever existed in the colonial context. That is, in reconstructing the situated perceptions and the materializations that the terror/fascination with difference elicited at individual and institutional levels in the past, one would produce a more intimate sense of the manner in which this difference had been regimented and played out in everyday life. How else can we begin to make sense of the sleight of hand that transformed "polluting" mixtures into "desired" ones? How else explain the shift of status of some groups from being polluting Others to being the archetypes of the creole nation? How otherwise explain the drastic shift of attitude that transformed "dangerous superstitions" into tourist attractions?

More specifically to my take on creolization within the realm of magic and religion, the short vignette on page 176 of this essay speaks more of illicit appropriations, ritual tactics, and the perceived symbolic hegemony of powerful others on a pragmatic level than of creole "mixtures" or "dialogues." The Catholic cross in the midst of African and Asian deities, I argue elsewhere (Romberg 2003c), is the tangible manifestation of past challenges to the exclusivity of the Catholic Church, as well as the illicit personal takeover of its most cherished symbols and gestures. Healing and magic rituals performed by brujos and other folk healers in altar-rooms such as this are proof of the successful takeover of the roles of priests and their gestures, as well as their repositioning to fit African- and Asian-based beliefs and rituals. ${ }^{3}$ Building on previous scholarship of African-based creole religions in the Americas ${ }^{4}$ and on my own research on brujería (Romberg 2003c), I suggest "ritual piracy" as a way to assess the complex process that entails these forms of religio-symbolic takeover. In this process a dialectic of two moments - the challenge to the exclusivity of the Catholic colonial order, and the recognition of its symbolic power - results in the unplanned rechanneling of hegemonic religious symbols to purposes other than those intended by the Church. 5

3. Puerto Rican brujería encompasses religious, healing, and magical practices linked to popular medieval Catholicism, popular Kardecean Spiritism (which includes, in addition to belief in the ability of humans to communicate with spirits, East Asian beliefs in reincarnation), and African-based creole religions such as Santeria (see Quintero Rivera 1998, Duany 1998, Romberg 1998, 2003c, Román 2000).

4. Cabrera 1975, Bastide 1978, Desmangles 1992, Brandon 1993.

5. I limit my discussion here to Catholic hegemonic symbols, but elsewhere (Romberg 2001, 2003a) I discuss how brujos took over other spiritual and bureaucratic symbols of power pertaining to nation- and state-building periods in Puerto Rican history and added them in their healing and magic rituals. 
Far from being a safe, mild metaphor for conceptualizing creolization as mixture, "ritual piracy" resonates with Stefano Harney's (1996:114-15) "predatory creolization." 6 Turning the traditional conceptualization of creolization on its head, he argues that, far from being the victim of cultural imperialism, creole nations such as Trinidad "devour and transform cultures local and alien" (my emphasis). Although "piracy" (and "predatory") might add a negative tinge to my revisionist project of creolization (as a colleague otherwise supportive of my thesis suggested), it encapsulates the kind of cultural moves that need to be recovered in discussing creolization processes: cultural plundering in the context of scarcity and monopoly - not mixture; and recognition of powerful others and tactical imitation of hegemonic culture - not dialogue. ${ }^{7}$

When translated to broader cultural processes, this predatory dimension of creolization (thus circumscribed) suggests a culture-making process that includes its negation, best characterized as "culture with an attitude" (Fabian 2001), or "in-your-face culture." 8 As I suggested in the vignette, an inherent "rupture of signification" (Taussig 1987:5) is evident when brujos, historically persecuted as heretics, redirect in their favor the same symbols that had persecuted them. Might this rupture of signification transmute into ritual excess that rechannels the illicit "copying" of Catholic gestures into magic potency? Could this be one of the wicked sides of creolization?

\section{Mapping "The Creolization Conundrum"9}

Before I continue with my argument, I wish to map a wide range of academic models that have been formative in one way or another not only in my own conceptualization of creolization, but in shaping the cultural politics of creole societies. I begin with those related to creole religions (specifically related to my research) and to cultural mixtures in general. I then discuss those frameworks that have addressed the locus, social carriers, scope, and effects of creolization processes, some of which have also been translated to

6. I thank Aisha Khan for suggesting this connection.

7. A parallel interpretation of creole economics as oppositional and subversive is developed by Katherine Browne (2004). I thank Richard Price for drawing my attention to her work.

8. As Abrahams said during a panel discussion at a meeting of the American Folklore Society in 2002.

9. I wish to thank one of the anonymous reviewers for suggesting this apt label for characterizing the kind of theoretical mapping I engage in here, which, in the reviewer's words, "indicates an acknowledgment that academic models and cultural politics are of mutual influence." 
emic meanings of these processes, thereby entering a local cultural politics. A discussion of the temporal dimension of this politics, which will historicize its native uses and its fictions, will follow this section.

Creole religions in the Americas - considered broadly the cradle of the creole concept - have mostly been discussed in terms of concepts such as "syncretism" (Herskovits 1937, Droogers 1989, Gort et al. 1989) and "acculturation" (Herskovits 1958), which were later enhanced as "symbiosis" (Desmangles 1992), "parallelism” (López Valdés 1995), “interpenetration” (Bastide 1978), “inter-system" (Drummond 1980), and "transculturation" (Ortiz 1995). Adding to this far from exhaustive list, a current reflexive scholarly energy within folklore, anthropology, religious studies, and literary criticism has been invested in assessing old and new concepts of creolization and the relative import these concepts have for describing and theorizing intense change across cultures. ${ }^{10}$ Some of these works directly add to my phenomenological revisionist project. For example, reviewing the etic meanings of creolization, Robert Baron (2003) and John Szwed (2003) conclude that "mixture" and "creative mixture" are key metaphors of creolization. Baron's (2003) wide-ranging list of evidence includes Ian Hancock's "compound"; Dell Hymes " convergence"; Herskovits' "intertwining," "merging," "blending," “coalescing," "telescoping," and "interpenetrating"; and Hannerz's "continuous spectrum." He also cogently traces some of these metaphors to the symbolic worlds of chemistry, mechanics, physics and biology, and in some cases to poetic/social models - for example, E. K. Brathwaite's "blood flow," "fluctuation," and "prismatic"; Daniel Crowley's "oscillation," and "inconsistency"; and Bernabé, Chamoiseau, and Confiant's "complexity" - that imply creativity and intermittent energy.

This is by no means a complete list, but it illustrates the rich scholarly attention given to conceptualizing situations of incommensurable contact via various metaphors of mixture. In the areas of religion, music, dance, and food, the study of "cultural creolization" (Spitzer 2003:58) has focused on the end result of creolization processes, leaving these processes mostly assumed a priori and unproblematized. According to O. Nigel Bolland (1992:64), one of the problems of considering creolization as a broad signifier for cultural processes of change is that it tends to assume a dualistic view of society - of oppressors/oppressed or European/African, for instance - that leads "to the portrayal of creolization as a 'blending' process, a mixing of cultures that occurs without reference to structural conditions and social conflicts." Rather, a dialectical approach to creolization implies, according to Bolland (1992:53), "a reconceptualization of the nature of colonialism and colonial

10. See, for example, the volume of Plantation Society (1998) edited by James Arnold, the special double issue of Caribbean Quarterly (1998) edited by Rex Nettleford and dedicated to Edward Kamau Brathwaite, and the Journal of American Folklore (2003) volume edited by Robert Baron and Ana Cara. 
societies, as social forces and social systems that are characterized by conflicts and contradictions, and that consequently give rise to their own transformation." Indeed, often taken out of specific historical contexts, as Aisha Khan (2001:272) poignantly notes, creolization has been used naively and redundantly as a metaphor for the creativity, agency, and empowerment of subordinate people. By focusing on the end result, a harmonious outcome has often been implied in such terms as "co-production" and "interconnectedness" (Khan 2001:273) - romantic, ideological views that stand in stark contrast to the ethnographic exclusionary power of "creolization" that she has encountered in Trinidad vis-à-vis Indo-Trinidadians. Khan (2001:272) therefore questions the descriptive and theoretical power of "creolization" for ethnography, and challenges its epistemological value "in terms of the referents that it both engages and creates, and the premises, often implicit, upon which it rests." Moreover, I would add, the epistemological boundaries between emic and etic uses of creolization have often been confounded in Caribbean histories when emic, native meanings of creolization (or their perception by scholars) have been invoked to inform social theory, the latter being deployed back into native practices, blurring, unless they are situated historically, the descriptive, ideological, and theoretical significance of "creolization."

But situating creolization processes historically and spatially has also been a thorny issue. Any retroactive explanation of creolization processes is complicated by the ideological investments in these processes after emancipation by nation-building agendas. Some situate creolization processes within the plantation (Trouillot 1998); others within the "plural" society - defined as multiracial, multilingual, and multicultural (Smith 1965); others within heroic, "grand" marronage societies (Price 1973, Mintz \& Price 1976). Still others, inspired by Kamau Brathwaite's (1971) creole society model, anchor creolization processes solely among intermediate groups (mulattos or such groups that emerged as a result of miscegenation). Because diasporic communities (descendants of non-African groups, such as Indo-Trinidadians) did not fit within the creole society model, they were excluded politically, culturally and conceptually from the imagined nation, even though they had historically always been functionally integrated into Caribbean political economies (Nettleford 1970, Khan 2001, Hintzen 2002:98).

In addition to this biased conceptualization of the creole society, the centrality and nature of creolization processes within nation-building projects have also been debated. Those that stressed the creative, integrative aspects of creolization in folk cultures envisioned it as a two-way process, defining it as "intercultural creolization" (Bolland 1992:58-59). Some have further portrayed this as a "synthetic" process that characterized the whole society, a vision that perfectly suited nationalist ideologies based on the integrative aspects of the creole community (Bolland 1992:64, Khan 2001:281). It is this view of creole ethnicity and nationalism that has promoted a highly hege- 
monic and exclusionary discourse of Caribbean identity (Khan 2001, Hintzen 2002). Others more sensitive to class differences have defined creolization, drawing on Orlando Patterson's schema of Caribbean societies, as a rather "segmentary" process that had differentially affected distinct segments of society. Following this schema, Richard Burton (1997:5-6) distinguished a continuum of overlapping and competing cultural forms, all of them creole or creolized, which he labeled "Euro-Creole," "Afro-Creole," and "MesoCreole' ('middle culture,' corresponding to the mesolect of 'middle language' of the free colored classes and certain sections of the slave elite)." Taking this lead, George Brandon (1993) pointed to the urban context, specifically to the cabildos or Church-sponsored fraternities, not the plantation, as fertile environments where urban slaves and freed people of color were able to develop a new creole religion, such as Cuban Santeria. ${ }^{11}$

Focusing on the social conditions behind creole processes, some anthropologists have recognized the kinds of microlevel creative forces that were needed to adapt to harsh conditions of existence, especially given the many sorts of structurally constraining social systems imposed in the Caribbean from colonization onward. ${ }^{12}$ Whether as forms of resistance, adaptation, retention, or survival, Sidney Mintz (1974), Michel-Rolph Trouillot (1982, 1998), and Roger Abrahams and John Szwed (1983) focused, each in their own particular way, on "interstitial" groups (Mintz 1974:146), historical and ecological "crevices" (Mintz 1985:131), and "systemic fissures" (Trouillot 1998:23). Among these groups and in these spaces, at the boundaries of rigid colonial systems such as the plantation, there were many systemic opportunities for the development of creole practices. It was in these places and spaces - such as in provisional plots of landless peasants surrounding plantations, during slave markets, and in the context of petit maronnage (when slaves used to run away to visit relatives, to take part in certain rituals, or sometimes to make a symbolic gesture of protest, Trouillot 1998:23) - that creole practices of both resistance and adaptation had emerged. "There was resistance, to be sure, and in a variety of forms," writes Mintz (1974:75-76), "But there was also accommodation, submission, degradation, and self-hatred. Moreover, it is clear that some of the most effective forms

11. In a similar vein Cuban anthropologist López Valdés (1985) traced the African-based ethnic components of nineteenth-century Cuban cabildos in explaining the creation of the religious creole practices of Santeria and Palo Monte. In addition, David Brown (2003) and Lorand Matory (mentioned in Price, forthcoming) trace the emergence of Cuban Santería and Brazilian Candomblé, respectively, to developments of religious creolization during the second half of the nineteenth century in mainly urban contexts.

12. Trouillot (1982:351) argues that "the motion in the system" (that is, change in worldsystem terms) was carried out by the gens de couleur, an intermediary group in SaintDomingue, whose "evolution happened to intersect with the development of coffee production" and who, "conscious of their marginality, turned this very marginality into an asset." 
of resistance were built upon prior adaptation, involving the slaves in processes of culture change and retention of a complicated kind." Suggesting we look at the cultural predicaments of this complex production in the interstices of slavery without assuming the total erasure of preslavery cultures, Abrahams and Szwed (1983) found similarities in the performance of African-style expressive culture. Especially in the areas of work (agriculture and husbandry), play, and religion, they note, "there were shared perspectives and a common conceptual and affective system of which the slave could not be stripped, and shared practices and beliefs and behavioral patterns which not only survived but were enlarged upon in the New World setting" (Abrahams \& Szwed 1983:10). Tracing the beginning of creolization processes back to Africa, Paul Lovejoy and David Trotman (2002) further refine the sources of influence by identifying critical differences among the various African populations that were brought to the Americas, contending (similarly to Robert Farris-Thompson) with the typical homogenization of "the African" component in studies of creolization. They note the differences among the enslaved Africans (with respect to their age, gender, status, and ethnicity, as well as the historical period in which they were enslaved and the stories they heard about whites) as to how they perceived their own enslavement in the Americas - perceptions that existed before the experiences they shared on slave ships and the eventual creation of creole cultures in the New World (Lovejoy \& Trotman 2002:69, 78).

\section{Creolization as a Native Concept: From Abomination to Celebration}

Historicizing its native uses and its fictions within the Caribbean can shed light on the complex social trajectories of creolization and the often contradictory referents it has gathered over time. The inspirational teachings of Nietzsche and Foucault on the historical, institutional, and power-based constitution of cultural value have provided me with the conceptual umbrella for this combined spatio-temporal approach to creolization, seen here - following William Roseberry's (1989:28) critique of Geertz's textual model of culture - not just as a product but as a production, "not simply as socially constituted but also as socially constituting." This approach implies a tracing of the power moves - both institutional (epistemic-based) and historical (genealogical) - that have been exerted in labeling things and people as creole, as well as a focus on the agents and agendas behind such native labels and fictions. Some have rightly warned against turning creolization into a master symbol of the Caribbean, for it could act as a gate-keeping concept that obscures real sociohistorical conditions (Trouillot 1992), or a particular fiction that "invents the region" (Khan 2001:272). Indeed, I argue that historicizing "creolization" would involve the inclusion of its fictions. The recent 
example of creolization being confounded with social theory and made into a symbol of Antillean identity has been produced mainly by Francophone, nationalist-minded intellectuals and artists who have reversed the early meanings of creolization - when Creole languages were vilified (as much as were the "mixed-bloods") for trespassing the godly taxonomies of the natural order (Dayan 1995:225, 228-29, 237-42, Abrahams 2003, 2002a) ${ }^{13}$ - into a desirable worldwide aesthetic program.

Recovering the various social class- and gender-based local meanings of "creole" requires revisiting both the institutional contexts of the bitter history they have emerged from and the symbolic wars of entitlement, as well the ridicule and persecution they have legitimized. Otherwise, as Abrahams (2003:79) notes, "the process of creolization becomes just one more name for the modernist or cosmopolitan project, one that encourages the coming together and the superimposition of peoples from many different parts of the world in a modern metropolitan polity." To recover this agonizing history, then, one has to consider, for instance, that the French Black Code of 1685 was "a document of limits" (Dayan 1995:203), setting the tone for planter/ slave excesses elsewhere in the Caribbean and the establishment of black/ white/creole racial taxonomies. Aimed at codifying the relations between planters and slaves, its sixty articles constituted blacks and slaves "not as persons but as a special kind of property: a 'thing,' according to Roman Law, juridically deprived of all rights. Legally, their being was 'a being-for-others,' and their civil status, that of things" (Dayan 1995:203).

Once creole societies entered the process of nation-building, the tribulations of creolization that resulted from such laws were silenced and smoothened to fit new nationalist agendas, a space that was not devoid of its own political economy, as will be shown below. The dubious inception of creolization during colonization did not prevent the subsequent revamping of Creoles and things creole, after their previous degrading connotations were strategically forgotten, as tokens of the new postemancipation nation in forging creolization as a symbol of the essence of the new national community. This ideology of the creole nation was established on the assumption that the social unity of the new nation was built upon a creole community (Bolland 1992:51) that was assumed to be the result of social and cultural creolization, or the blending of racially and ethnically diverse groups. This populist and culturalist ideology was forged, Bolland (1992:53) notes, in the last quarter of the twentieth century by "a middle-class intelligentsia that [sought] the

13. "Uncontrollable concubinage and licentiousness," Dayan (1995:238) notes in reference to the writings of white nature-scientists of the eighteenth century on racial degeneration - were considered by some as producing "unholy mixtures" or in the words of a colonial administrator in 1722, "a criminal conjunction of men and women of a different species," giving birth to "a fruit that is a monster of nature." 
leading role in an integrated, newly independent society." Turned now into a state ideology, creolization was to signify the idea of creative, not polluting, mixtures. Yet this nationalist ideology of creolization has been questioned for its assumed "harmony." Rex Nettleford (1970:173-211), for example, draws metaphorically on the semantic opposition between melody and rhythm to claim that Jamaican society has created a harmony in which the melody takes precedence over the rhythm; or, in sociological terms, "the mixture has produced a Creole culture in which European and African elements persist and predominate in fairly standard combinations and relationships with things European gaining ascriptive status while things African were correspondingly devalued" (Nettleford 1970:174).

Notwithstanding this and other critiques, the nationalist ideology of creolization was articulated and transformed into an aesthetic trope within the Francophone literary field of creolité. Created as a native, elite cultural manifesto, In Praise of Creoleness (Bernabé et al. 1989) transformed the nationalist ideology of creolization into an all-encompassing, quasi-universalistic ideology aimed at celebrating the creativity and heterogeneity of creole culturemaking processes as an alternative to the previous attempts of the négritude and indigénisme artistic movements to seek a Caribbean identity. They write,

\begin{abstract}
We cannot reach Caribbeanness without interior vision. An interior vision is nothing without the unconditional acceptance of our Creoleness. We declare ourselves Creoles. We declare that Creoleness is the cement of our culture and that it ought to rule the foundations of our Caribbeanness. Creoleness is the interactional or transactional aggregate to Caribbean, European, African, Asian, and Levantine cultural elements, united on the same soil by the yoke of history. (Bernabé et al. 1989:87)
\end{abstract}

This manifesto fitted well into the nationalist ideologies of the authors and their artistic claims; but when it became uncritically transvalued as social theory, for instance within globalization theories of culture, hybridity, and creativity, its consequences proved detrimental for the study of the sociohistorical aspects of creolization processes. ${ }^{14}$

Since these artistic and theoretical trajectories of creolization are also parts of the history of creolization, they refract back, producing their own contradictions in scholarly, literary, and tourist projects. For example, the manifesto writers of the creolité movement (Bernabé et al. 1989:97) acknowledged the paradox of exclusion and commodification when the state and commercial entrepreneurs sponsored creole folk expressions.

14. For critiques of In Praise of Creoleness, see Condé \& Cottenet-Hage 1995, Condé 1999, and Price \& Price 1997. 
There were some insignificant reproducers of misunderstood gestures, some modest collectors of useless memories; there were some obscure directors of commercialized culture for tourists more curious about us than we were; there were some dull epigones of a hackneyed speech, some naive promoters of a trite carnival, some industrious profiteers of a strident, loud zouk. They rarely escaped the assertion - shouted or whispered - of doudouism and folklorism. But in the final analysis they were the indispensable links that contributed to save Creoleness from the glorious yet definitive fate of Atlantis.

Indeed, the transformation of "polluting" others into commodified postcard icons of island harmony, creativity, and exoticism is in itself a mystery, sociologically speaking, requiring more than a dialectical frame of analysis that includes its critique; it requires also the insights of poetry and magic. The life and memories of Médard (a Martiniquean artist/convict/legend), exquisitely articulated by Price (1998:157), illustrate this mystery of seduction, fear, and magic, a mystery portrayed by Michael Taussig (1993) as a chamber of distorting mirrors, of magic and mimesis, resistance and adaptation. This mystery, and the sense that probably the silences of history may be imagined but never totally recovered, becomes evident when Price places side by side recovered bits and pieces of the life of Médard and the memories recounted about him. We learn that Médard "stole" from the masters to give to the poor, made exact "photos" or carvings of colonial symbols of power (such as ships, people, and musical instruments), and was imprisoned and exiled. The relationship between madness and colonialism becomes evident in these bits and pieces of his life history. In the context of nation-building, this madness is signified in a "theater of marginality" that commemorates the memory, not the life, of Médard. This marginality is further selectively remembered and exploited for tourist consumption, while the colonial life of Médard is carefully forgotten. As Price (1998:173) succinctly and evocatively notes,

\footnotetext{
What we are witnessing ... might be called "the folklorization of colonialism," or the "postcarding of the past." Indeed, during 1987, influenced by state efforts to recuperate the patrimoine culturel (the official heritage of this corner of France), as well as to promote tourism, a local youth group sponsored by the municipality of Diamant renovated Médard's house, cleaning up the graffiti slapped on by some Rasta visitors, repairing the carpentry, creating a picturesque rock-inlaid walk leading to the front door, repainting the wood in approximations of the original colors and, voilá, every tourist shop in the capital of Martinique began selling postcards labeled "Diamond Rock and its legendary 'House of the Convict.",
}

It is striking to see how initial native meanings of creolization - related to broader notions of contagion, deviancy, and abomination - were transformed within the new ideology of nation-building, following emancipation, in ways that indexed a wholesome homogeneity of heterogeneous multilingual, multiethnic, and multiracial societies, epitomizing what modernity was assumed to 
consist of (Brathwaite 1971, Bolland 1992). Furthermore, the reinsertion of creolité aesthetics by Caribbean Francophone writers as a trope with revolutionary potentials in postcolonial (gender and class-blind) cultural politics ${ }^{15}$ points to the relevance of revisiting the historical conditions under which native notions of creolization were constituted. ${ }^{16}$

But who recorded and who compiled creole practices? In his reflections on the structural silences of the past, Trouillot (1995:2) muses over the fact that "human beings participate in history both as actors and narrators." Obviously, some creole practices were either not documented or, if so, not archived; others were either misrecognized or only selectively narrativized; and still others were only embodied much later in fiction, monuments, and commemorations. Due to the systemic silencing of certain events and groups, the "miracle" of creolization processes (Trouillot 1998), their contentious, experiential, and sensorial meanings will probably escape analysis altogether.

With this obstacle in mind, however, I am aware that situating the elusive, often oppositional transformative processes around creolization processes requires, following Trouillot's (1998) call, echoed also by Price (2001, forthcoming), a refined look at their historical particulars. In this case they entail the examination of systemic fissures, colonial scarcity, entitlement wars, double-bind rules, as well as their unintended consequences. This goal informs my examination of the microtechnologies of magic and ritual piracy from a combined ethnohistorical and ethnographic perspective. I am also aware that this project partly requires a phenomenology that is historical, and a complex project of historical/sociological reconstruction and imagination, which, due to the lack of firsthand accounts, might verge on the fictional. Or perhaps this past, with its lost voices, might be recovered, following Paul Stoller (1997), bit by bit in discursive and embodied practices, and sensorial memories, in the present. For Pierre Bourdieu (1990:56), these forms of embodied history would constitute the habitus, "internalized as a second nature, and so forgotten as history" and as such would be "the active presence of the whole past of which it is the product."

In spite of a rich scholarship on creolization, and the general contextual assertion held by many that "questions of power, as well as issues of entanglement" (Hall 2003a:31) prefigure creolization processes, the microsociocultural and existential production of creolization, as it is historically

15. Price \& Price 1997, Condé 1999, Schwartz \& Ray 2000, Yelvington 2001, Enwezor et al. 2003.

16. Condé (1999:97) for example launches a critique of the creolité literary movement based on what she sees as the "Carnivalization" of French Caribbean literature and the basic divorce of its intellectuals from the real experiences of Caribbean Creoles, suggesting that intellectuals have failed their self-appointed revolutionary mission, leaving only "the pyrotechnics of the text." 
and geographically situated here, is still shrouded in a black box of magic and mystery, like the magician's top hat.

What are the sensorial mechanisms that have been involved in these uncanny productions? To grasp their entangled micro-sociopoetic technologies, I propose peeking, following the above analogy, into the magician's hat immediately after he has tossed European, African, and indigenous practices into it and pronounced the famous abracadabra, and just before he pulls out creolization. Assuming the contentiously constitutive nature of creolization processes, in contrast to "dialogue," "eclecticism," and "cross-cultural hybridity," I ask, "How do seduction and fear, domination and impertinence, as well as scarcity and artifice, fashion what happens in the top hat?" Considering the technologies of magic both in descriptive and heuristic terms, the mystery behind the creole sociocultural transformations that occur inside the "top hat" can be imagined (as I hope to show below) as a form of magic, no less than the technologies of magic can be regarded as forms of creolization.

\section{Entitlement, Ridicule, and Fascination}

Ethnohistorical records tell us that colonial encounters were more complex than the scenario of one group dominating or extracting the labor of others by sheer force; and that there were moments mediated by sheer fascination and fear of the unknown as well as opportunities for experimentation (Abrahams \& Szwed 1983). Complex local and metropolitan race relations, economic exploitation, and political domination, as well as cultural entitlements and laws that protected them, mediated the multifaceted perceptions that competing groups held of each other. Joan Dayan (1995:224-25) keenly illustrates this point, showing the intricate feelings of intimidation and alliance felt by competing social groups in colonial Saint-Domingue:

\footnotetext{
White women envied women of color; petits blancs despised the free coloreds, whose sobriety and talent made them tough competitors; the established sugar planters were threatened by the extraordinary boom in coffee plantations, mostly owned by enterprising mulattoes; and the metropole kept trying to restrict emancipation, since the mulatto's links with enslaved maternal relatives could erode white racial hegemony and thus threaten slavery itself. Little did the king's lawmakers suspect that some of their fiercest allies and most devoted followers of the style and taste of the Old Regime would be mulattoes.
}

Its precarious stability always threatened by disruption and annihilation, the colonial order was not only marked by economic exploitation and political domination, but also mediated and sustained by the spontaneous performance of cultural displays of power, which, once adopted by the lower ranks of society, became the objects of strict policing and legal prohibitions. 
Political and economic colonial rule was legitimized, among other things, by a very intimate, personalized form of cultural imperialism that assumed the uncivilized nature of the oppressed. A savage and primitive nature that could be "elevated," the story went, only by the strict civilizing power and guidance of Europeans. Trouillot (1995:75-76) reminds us that during the seventeenth and eighteenth centuries,

\begin{abstract}
the more European merchants and mercenaries bought and conquered other men and women, the more European philosophers wrote and talked about Man ... [W]ith its extraordinary increase in both philosophical musings and concrete attention to colonial practice, the century of the Enlightenment was also a century of confusion. There is no single view of blacks - or of any non-white group, for that matter - even within discrete European populations. Rather, non-European groups were forced to enter into various philosophical, ideological, and practical schemes ... that recognized various degrees of humanity ... [and assumed that] some humans were more so than others ... On reflection, and only for a timid minority, Man could also be westernized man, the complacent colonized. The benefit of doubt did not extend very far: westernized (or more properly, "westernizable") humans, natives of Africa or of the Americas, were at the lowest level of this nomenclature.
\end{abstract}

In the Spanish Caribbean, Catholicism served as one of the major tools for effecting this expected transformation or westernization, which served implicitly to sustain and legitimate the civil and politico-economic domination of Spanish rule. It was therefore crucial that ruling classes secure total control, domination, and subjection (in Foucault's terms) of the colonized not only politically and economically but also culturally and in religious matters. Dominion over markers of group affiliation, status, and rank (such as religious worship, language, clothing, and gestures) were central to maintaining the colonial order and its status quo. Numerous documents attest to the increasing prohibitions and control over vernacular worship, funerary rituals, religious festivities, leisure activities, and dress that expanded the official definitions of the nature of these practices and the social groups that were entitled to them. These prohibitions, however, "responded to practice" (Dayan 1995:248); they were not reflections of an a priori philosophy of domination but a reaction to emergent though often subtle forms of social blurring of colonial categories and entitlements. They were established only after these vernacular appropriations of official mores seemed threatening, and were imposed as a result of the fear of the colonizers that their precarious social order would collapse, signaling imminent internal upheavals and large-scale revolts. They became even more draconian after the Haitian Revolution. What the civil and religious authorities (especially those on plantations) feared most were the kinds of "licentious behaviors" that under the pretext of religious worship could lead to a bloody end of the slave system, as 
well as of the colonial order itself. Fear of "licentious behaviors" also threatened future postemancipation societies and in fact resulted in the concerted hounding of festive and religious vernacular practices (current versions of which are now celebrated and offered for global tourist consumption).

But the totalizing social order that colonial institutions and laws had aimed at forging and maintaining from the very beginning of colonization proved, retrospectively, to be failed projects. Vernacular practices developed in reference and opposition to political, economic, religious, and cultural colonial orders, and managed to exist both alongside and in symbiosis with them. These vernacular practices and, more broadly, creolization processes developed within these structural conditions in ecological, historical, and sociocultural spaces, best characterized as systemic interstitial zones (Mintz 1974, 1985).

Examining these systemic interstitial zones through a phenomenological lens suggests that they have shaped creolization processes not just because of the obvious need of both colonizers and colonized to adapt to new, harsh conditions in the New World, but also because they provided spaces in which both colonizers and colonized were able to measure each other's creole behaviors. In their desire to reproduce, with whatever means available, the worlds they had left behind, the alternative worlds they actually managed to recreate as a result of the forced contact they had to endure ended up failing, as if always falling short of the worlds each group had imagined having lost. The unease that these failings caused to arise among representatives of colonial power is well documented in historical records, according to Karen Fog Olwig (1993), attesting to an inherent "cultural struggle" between colonizers and colonized. Reporting, for instance, on slaves' Sunday markets, "tea meetings," or "Christmas sports," these documents address the more or less "uneasy recognition of the Englishness of these institutions or traditions," while showing that European observers also critically acknowledged that "these cultural forms were no longer English but had undergone a transformation as they had become appropriated by the Afro-Caribbean people" (Fog Olwig 1993:203, my emphasis).

Rather than accepting unproblematically the fusing of the worlds left behind as creative "mixtures" (or "dialogue among cultures"), as proposed by nationalist ideologies of the creole nation and some globalization scholars, these "mixed" alternative worlds elicited conflicting reactions of fear and desire of mixtures (Livingston 1992, Young 1995). Self-deprecation and fascination with others, and replication and fear of illicit imitations, all bounced off the perceptions of colonizers and colonized alike, both having been dislocated from "pure" civilizations, with the obvious difference that only the former had the power to police the outcome of these perceptions.

In the process of settlement, metropolitan immigrants - marginal to their own societies - tried to reproduce the metropolis in the New World, imitating the Old World's architecture, religion, fashion, way of life, and etiquette. 
Resulting in imperfect copies, these outrageous attempts, in an age in which purity and civility were being celebrated, were depicted by travelers, military envoys, and religious missionaries as forms of "Creole contagion," pollution, and "depravity" (Abrahams 2003). The desire and then failure to reproduce "pure" civilizations informs the colonizers" obsession with " Criolian degeneracy,' [which was] 'a theme of transatlantic discourse' almost from the moment of settlement" (Kupperman, quoted in Abrahams 2003:81).

Creole cultures were regarded by metropolitan observers as degrading and contaminating, according to Abrahams (2003:76), since these outposts of empire were said to be composed of "congeries of people brought together for the production of surplus crops [who] were considered corrupt simply because they were such a hodge-podge of vagrant peoples" whose mode of expression was not deemed a "real language" but a "nonsystem of expression made up of bad, broken, and incomprehensible sounds." Further, "these people, whether slave or master, were too distant from metropolitan power. Social order and practice of 'civilized' people were constantly being eroded." Like slaves, outcasts of mixed blood were perceived - within the prevalent Enlightenment's racial theory of purity and hybridity - as "lazy" and driven by "lust," which "led them into the worst excesses of the savage state" (Abrahams 2003:76). Extending racial pollution to economic practices, colonial marketers were "enormously troubling to the elite social structure of those in European cosmopolitan centers. No one knew what to make of these raw, rich, and economically volatile colonials," who were getting extremely rich by adding to the "sins of skullduggery and lying, endemic to market traders," the deceitful "complications of double bookkeeping" (Abrahams 2003:77).

The transgression of established European taxonomies - say, of the difference between races, upon which exploitation in the colonies was made morally possible - is for Dayan (1995) a major explanation for metropolitan and elite colonial perceptions of pollution in colonial Saint-Domingue. Some of these transgressions were perceived as "misalliances," resulting from creole blood-mixings (of whites and people of color, for example) and inappropriate relocations (people of color behaving like, or inhabiting spaces reserved for, whites). Further threatening the whole colonial order, in particular slavery, "the European model of beauty, once exported to the colonies, began to seem as misplaced as outmoded Parisian goods in a Creole market. The imported ideal ran up against the fact of 'misalliances' that debunked the myth of the repugnant black: the physical deformity so necessary to the invention of the servile soul" (Dayan 1995:222).

Interestingly, not only did white Creoles despise and debase blacks imitating them, but also metropolitan whites bitterly ridiculed Creole elites on the islands for imperfectly imitating metropolitan society. "What is allowed, admired, or unquestioned in Europe becomes ludicrous in the colonies," Dayan (1995:172) remarks. "The glories and refinements of the Old Regime, 
when practiced by those who did not inherit the right to do so, can be nothing but the worst kind of imitation, degraded and degrading. When does luxury become cheap? When does love become debauch? Some answered, "When Paris comes to Saint-Domingue." Illustrating the perceived colonial degradation at the linguistic level, and the need of the upper classes to preserve the highly vulnerable hierarchical order they had created in the colonies, it is worthwhile to examine the impressions recorded in 1839 by Lady Nugent, which were marked "simultaneously by the ludicrous racism of a nineteenthcentury New Jersey belle married to a Jamaican governor, and by endless assertions of her own humanitarianism" (Mintz \& Price 1976:17). Speaking of breeches in linguistic propriety among the elite, she notes,

the Creole language is not confined to the negroes. Many of the ladies, who have not been educated in England, speak a sort of broken English, with an indolent drawling out of their words, that is very tiresome, if not disgusting, I stood next to a lady one night, near a window, and, by way of saying something, remarked that the air was much cooler than usual; to which she answered, "Yes, ma'am, him rail-ly too fra-ish."17

Fear of contagion also explains the contempt expressed by colonizers for the speech of the colonized, which might have been intelligible but never close enough to their own speech. Mervyn Alleyne (1985:160) argues that creole languages developed by Africans and their descendants were evaluated by Europeans as "pathological" versions of European originals, as " deficiencies,' 'corruptions,' and 'mutilations." In his landmark study of expressive creole speech, Abrahams (1983) shows that not only words but also European "speech events" were especially valued and imitated by underclass groups, who identified the plantocrat's power with his European tongue. From the Europeans' perspective, and due to a basic ethnocentric misunderstanding, these performances were seen as "a corruption of the European practice" (Alleyne 1985:26). ${ }^{18}$ Further, the appropriation of European genres, say of ornamental

17. A similar disjuncture among white metropolitans and white Creoles around the metropolitan fear of colonial contagion, madness, and depravity was in evidence in the film Wide Sargasso Sea (based on the novel of the same name by Jean Rhys 1996). In the film, this disjuncture appears in a series of finely staged gestures and looks that index iconically the inappropriate behavior of a Creole woman at a party pretending to be somebody she is not; that is, for adopting the pose of an English woman, yet lacking real English upbringing.

18. Prohibitions and exclusionary practices also forge their own transgressions and play with transgressions, as evidenced by various forms of tactical contestation, which many characterize as creole in nature. For instance, folklorist Ana Cara (2003) looks at the Argentinean hablar en criollo (creole talk), exemplified in the turns and tricks of creole speech practice during the card game Truco, played by the Argentinean people and superbly fictionalized by Jorge Luis Borges. Creole talk, she writes, "is the art of "telling 
speechmaking in weddings, by Afro-Americans seemed ludicrous and absurd for European observers, since it seemed to emerge out of a childish will to copy and pretend, and an intellectual inability to do it well, not realizing that it was a code substitute for African traditions of eloquence (Abrahams 1983). ${ }^{19}$

The ridicule it raised among the upper classes cannot be overlooked as another form of repression, subtle as it might be. Indeed, in any discussion of creole processes, such as delimited here, one should keep in mind that things creole have been de-authorized, ridiculed, and sanctioned under the civilizing ideology and practice of colonization as contaminating, disorderly, and regressive (its people, as lazy, childish, and wild) (Abrahams 2003). Fear of these transgressions among the underclass created not only a "comedy" - as in the upper classes - but also a "tragedy" of color and race among the subaltern classes.

Placing this tragedy on the misuse of luxury items by free people of color, Moreau de Saint-Méry records the words of a traveler to Le Cap, who overheard an upper-class white lady exclaim, when she saw three mulâtresses in muslin skirts, garnished with lace: "Look at these rotten pieces of meat! They deserve to have their lace cut flush with their buttocks and to be sold on the fish table at the Clugny Market" [the Negro Market]! (quoted in Dayan 1995:222). The closer these transgressions were to white society the harsher the visceral reactions. "The promise of same rights, privileges, and immunities" to be given to freed slaves as to those born free, expressed in the Black Code had been perverted, according to Dayan (1995:223), as a way to protect "white supremacy." Economically successful "people of color" were the target of much repression. Trouillot (1982) suggests that vexations and new restrictions on the civil rights of freedmen after 1760, such as the "dubious interpretation" of "disrespect" as defined in the Black Code, were triggered by the economic success of some entrepreneurial gens de couleur who profited largely from producing coffee in areas vacated by white planters in ways that allowed them to use their scarce resources in optimal ways. ${ }^{20}$ This harsher treatment of economically flourishing people of color, then, and the imposed restrictions on wearing European-style clothes or displaying any signs of sta-

it like it is' ... is to say the conventionally 'unsayable' by twisting language around (e.g., through humor, understatement, double entendres) or using words in such a manner that a truth (normally not part of the dominant ethos) is confirmed or revealed" (Cara 2002:40). For creole poetics, see also Haring (2003).

19. A telling pamphlet, "A Black Lecture on Phrenology," accompanied by a visual representation of the ridicule that the eloquence of free slaves produced among white elites is reproduced in Hall (1997:246).

20. Furthermore, Bastide (1978) refers to restrictions of dress and gesture among the high-status professional mulattoes in Brazil, who were forbidden to wear European-style shoes, for example, or to go to the opera. 
tus (such as lace, silk, jewelry, sabers, and even on naming practices) were the direct result of an inherent racially motivated threat of creole forms of economic success to the hegemony of the European order in the colonies. ${ }^{21}$

On the other hand - in light of the rupture and break from home cultures and ways of life - imitating the culture and religion of powerful others was not only a way of survival for the many underprivileged groups that were brought by force or cunning to the New World (as many have suggested) but also the source of a less disempowering form of adaptation. On the one had, their survival depended on their ability to appear to have been westernized, yet they were ridiculed and often disciplined and punished for doing so. In this contradictory cultural space, those who managed to live in these two worlds were often perceived as madmen or sorcerers. As Price (1998:161-62) reminds us, "the dozens of memorable 'madmen' of Caribbean fiction are not just literary tropes" but real-life models who have to live "in a world where the circumstances of life are deeply contradictory ... Many of 'the mad' are not just finding a personal way out - they are carving out a solution, however unreasonable, for a society-wide, existentially absurd situation. Their retreat or riposte, whatever their iconoclastic form, often makes social sense."

Although copying or imitating was not only expected by the colonial civilizing project but also seen as a reasonable way of adaptation, it created a sense of danger or taboo, in Mary Douglas's (1966) terms, in regard to the in-between social spaces it created. Such spaces can be best characterized as emerging out of the "partial presence" of the original, which results when the boundaries that had been established by means of particular forms of speech, demeanor, dress, leisure, exchange, etc. in order to distinguish one group from another are blurred by the imperfect copy or reproduction of these symbols and gestures. It is in the context of the colonial quest of reproducing or copying as faithfully as possible legitimate white homogeneous culture (not that such pure homogeneity ever existed) that the threat and fear of mélange (racially speaking) and heresy or unauthorized copies and resemblance (culturally and religiously speaking), acquire disturbing proportions, inspiring the creation of draconian laws and edicts that were meant to restrict the opportunities for such "abominations" to occur in interstitial colonial spaces.

The power and magic ascribed to people located in cultural interstitial zones, at borders, or at social crossroads is well documented in anthropological literature (Douglas 1966). Both revered and feared for their transhuman powers, dominated groups located in ecological and cultural margins can become the object of accusations of magic by those inhabiting orderly centers of power. In the colonial context, indeed, these marginal groups were

21. For a detailed account of the restrictions established on naming practices, and on the display of luxury items among those light-skinned mulattoes - those "suspects" trying to pass as whites - see Dayan (1995:226-27). 
both feared and respected for their ability - real or imagined - to heal as well as to poison (Taussig 1987). ${ }^{22}$

The growth of these marginal groups began early on in Puerto Rican colonial history within "internal frontier" areas (Mintz 1971:486), where some settlers, realizing the economic opportunities offered by illegal trade, opted for moving outside the walled capital, instead of following the mandates of the metropolitan orders. These groups, composed of native Indian and Creole peoples, subsistence farmers (characterized as squatter-type peasantries by Mintz [1971:486]), former convicts, shipwreck survivors, pirates, freed people or libertos, and runaway slaves from the island and neighboring islands, which Angel Quintero Rivera ${ }^{23}$ identified as forming a sociedad cimarrona (Maroon society), were left almost completely on their own not so much by choice as by necessity: a direct consequence of the geographic and colonially imposed economic marginality of the island of Puerto Rico. ${ }^{24}$ By and large this sociedad cimarrona included what Mintz $(1971,1974)$ characterized as squatters, runaway peasantries, and agregados (sharecroppers, who in 1775 exceeded the number of slaves). The first were composed of "peasantries of mixed cultural and physical origins [which] seem to have come into being as a mode of escape from official power" (Mintz 1974:147); the second were Maroon communities formed "in defiance of slavery and the plantation system" (Mintz 1974:152); and the third, considered of European descent, contributed a certain portion of labor (to plantation owners) as a form of rent (Mintz 1974:92-93). Such forms of petit marronage were further maintained as a result of their demographic isolation and the debilitating scarcity of both funds and people typical of this Spanish colony.

This forced isolation promoted typical forms of social and cultural marronage in the interstices of colonial society, which in the second half of the nineteenth century evolved, in relation to coffee haciendas, into a particular form of highland creole peasant culture, characterized by Jorge Duany (1985:112) as "semifeudal" and infused by relations of "deference and paternalism," later known and romanticized as the ways of the jíbaro (a poor, supposedly white peasant). Besides creating local structures of feeling and behavior, they were largely responsible for reshaping indigenous beliefs and medieval Catholic

22. Among these groups, mulatto women stand out for the vast documentation on their conflicting personal and natural characteristics. In colonial Cuba, for instance, they were imagined and indeed represented in scientific reports, literature, theater, and popular culture as endowed with pathological characteristics that made them the most beautiful and mischievous seducers, the most knowledgeable healers, and the most dangerous sorceresses (Kutzinski 1993, Dayan 1995, Moore 1997).

23. Personal communication, 1995.

24. This state of affairs was modified at least at the economic level, when poor landless Creoles of various racial and ethnic background were recruited as forced labor and required to carry the infamous libretas, or workbooks, following the police and government regulations of 1837 and 1848 (Mintz 1974:91-92). 
practices into a local form of vernacular Catholicism, characterized by highly individualized anticlerical forms of Catholic worship. This form of creole folk Catholicism was sustained in the countryside mainly as a form of anticlerical worship that took over the major functions of the Church. Some analysts, such as Jaime Vidal (1994), argue that because of its perpetual underfunding, the Spanish Church never succeeded in controlling the faith and rituals of Puerto Ricans. Ramón Grosfoguel, Frances Negrón-Muntaner, and Chloe Georas (1997:30-31) aptly use the folk term jaibería (astuteness) to denote a wide range of popular practices of resistance to, and negotiation with, colonialism, "of taking dominant discourse literally in order to subvert it for one's purpose, of doing whatever one sees fit not as a head-on collision ... but a bit under the table" (see Browne 2004). The history of Puerto Rico shows that this jaibería has shaped demographic and ideational local responses to globalizing forces, hindering the formation of a homogeneous Catholic society and a passive, acculturated slave and "free-labor peasantry" (Mintz 1974).

In view of the establishment of populations on the mountains outside colonial centers, far away from churches and chapels, the religious hierarchies authorized and promoted Catholic worship in provisional spaces such as ermitas (small country chapels). Further, due to the endemic lack of priests on the island, services were conducted in these small countryside places of worship by devotees (rezadoras) who had proved in some way their devotion and/or spiritual qualities (Vidal 1994:21; 213 n. 36). The Church also promoted cofradias (lay fraternities). But who could really control what was going on in these services?

Indeed, after centuries of being persecuted by the Church, Puerto Rican brujos pursue an essentially anti-ecclesiastical attitude toward religiosity. Even today they appropriate the Church's symbols (still recognized for their power, following the colonial experience of imposed religion and civility), smuggling their own agendas into them. Summoning the powers of the Catholic Church, brujos incorporate them in the making of their trabajos or magic works. Mimetically, brujos are able to conjure and redirect the transcendental powers embodied in Catholic gestures and signs (that had hitherto persecuted them) transmuting these powers into their own trabajos. Today we can see that brujos are not only versed in Catholic worship but that they also take over the role of priests, praying the novenas for their deceased clients, and performing special "baptisms" as a form of cleansing and "spiritual" weddings as a way to restore the bond between married couples (Romberg 2003c). Like the bush priests of Haitian Vodou and the priests of Brazilian Candomblé, Puerto Rican brujos invoke the power of God when asserting their spiritual gifts, spiritual mission, and healing abilities. ${ }^{25}$ Following the

25. The integration of Catholic and African forms of worship found in creole vernacular Afro-Latin religions such as Haitian Vodou and Brazilian Candomblé offer comparable examples of the deterritorialization of the sacred. Recognizing the exclusive power 
Catholic genre of miraculous apparitions, brujos recount their miraculous beginnings in reference to an uncanny encounter they had with God or the saints. They also portray and frame their "godly gifts" and "mission" as healers following the teachings of Jesus and his parables. Haydée, the bruja with whom I worked as an apprentice in Puerto Rico, always asserted this idea in the various situations of her spiritual work; before opening her altar for consultations, for instance, she would say, "God gave me the blessings and the abilities [dones] to heal, and in abundance! ... Without God, I don't do anything. God is the one [who heals]" (Romberg 2003c:111).

The same crucifix that was once the persecutors' spiritual shield against brujos has turned into the protective shield of those who had been persecuted. Not only Catholicism's narrative genres but its gestures and prayers have become part of cleansing rituals against evil spirits, and been invoked as protective shields against evildoers, and performed to empower magic works. The appeal of Catholic signs, gestures, visions, and miracles to brujos, considered "heretics" since colonial times by the Church, will be further elucidated once the technologies of magic and the power of negativity have been considered in tandem. This is where the power of negativity (Fabian 2001) transmutes into processes of creolization, camouflaging the hidden ends of mimesis; this is what I mean by "creolization with an attitude."

\section{SCARCITY AND RituAl PiRACY}

If creolization processes emerged out of responses to the fascination and terror of mixtures, they also involved the transmutation of the cultures of the original groups into new ones, which in the words of Trouillot (1998:8) is still "a miracle begging for analysis." The conditions under which such a miracle was produced were those of economic and (in some ways) cultural scarcity (Abrahams 2002b). ${ }^{26}$ It could be a major difference with other parts of the world noted for their creolization processes, such as India, where at the time of colonization an already complex society, shaped by mercantilist global trade routes, had existed for centuries. Comparatively, the Caribbean

invested in the colonial Catholic state to constitute the idea of civility, the relocation of Catholic worship into Candomblé terreiros (temples) might have been intentional. It could also have been indicative of the symbolic translocation of Catholic legitimacy to the terreiro, and not just, as usually portrayed, of the unreflexive mixing of African and Catholic beliefs. Similarly, some elements of the experience of Catholic worship have migrated to empower the space of the Haitian ounfo (temple) through the prayers of the prèt savann (a ritual specialist versed in Catholic prayers).

26. I thank Roger Abrahams for drawing my attention to the issue of scarcity. 
from its very inception had been marked by economic scarcity, and following the destruction of its indigenous populations in the first decades after its conquest, by sociocultural scarcity as well. Assuming this particular context, various writers have imagined the world of creolization as characterized by "chaos" and the productivity of the unknown (Benítez Rojo 1992, Glissant 1997). Capitalizing on the potential of Glissant's theory of creative disorder or chaos for articulating experiences of global flux and fragmentation, some postcolonial globalization theorists have suggested a parallel between the creative, contestatory logic of that plantation experience of chaos and today's urban, postcolonial, postmodern experiences. ${ }^{27}$ Plantation societies were not the only hubs of creolization processes, as noted above; urban colonial centers, marked as they were by existential conditions of scarcity, gave rise to the development of intricate informal markets operating on their margins, becoming fertile grounds for religious and cultural creolization processes (Abrahams 2002a, 2002b, 2003). ${ }^{28}$ But, of course, scarcity was played out and had different outcomes for Europeans, Creoles, and Africans of distinct social positions. Various interstitial groups - pirates, buccaneers, and Maroon societies (especially Catholic folk healers among the latter) - structured their tactics of survival on the margins yet, at the same time, in close if adaptive parasitic relations to local and metropolitan centers of power.

The metaphor of ritual piracy I am suggesting here for creole religions has been inspired by these kinds of Caribbean histories, which show the intricate dependency of the margins on centers of power, on their demands, desires, and symbols. The creation of Maroon societies and Maroon cultures, and the pirating and privateering that persisted in the New World, attest to the paradox arising from the simultaneous acceptance and rejection of metropolitan powers on the fringes of the social order. Initially, a local Caribbean response to monopoly mercantilism that subsequently often transformed into clandestine support of Creole uprisings, "piracy" encapsulates a typically Caribbean pioneering force. For instance, once approved and even sponsored by seventeenth-century metropolitan powers (French, Dutch, and English), privateering turned illegitimate and was prosecuted as piracy when European interests had shifted from mercantilism to a capitalist plantation economy. A few pirates actually became the governors of some Spanish islands after the captains of the "Western Design" snatched those islands. Undoubtedly these were not the sole examples of "artful" forms of partnership between centers

27. Chambers 1994, Balutansky \& Sourieau 1998, Enwezor et al. 2003, Hall 2003 b.

28. For example, the same marginalized people and "madmen" who spent the whole year in the forest were brought down to the village and recruited to perform at festive events (Abrahams 2002b). Similarly, Catholic devotees who were recruited by the Church to help conduct services were later responsible for creating their own versions of the liturgy in their altar-rooms at home. 
of hegemonic power and their margins. For mutual dependency and cunning have inspired other parasitic relationships in the Caribbean since colonization, such as those between piracy and imperial commerce; privateering and metropolitan interventions in Latin American independence wars; Maroon economies and plantation systems; and, currently, between informal economies and global markets. These tactics resonate with native trickster modes of economic as well as cultural survival such as jaibería, mentioned earlier (see Grosfoguel et al. 1997:30-31).

Although vernacular religions operate at the margins of society, their practices are paradoxically dependent upon and opposed to power centers (whether religious, political, or economic) (Williams 1980, Cantwell 1993). This paradox is best illustrated in Puerto Rico by the consequences of the establishment of ermitas, rezadoras, and cofradías. These Church-sponsored practices in time become a threat to the very hegemonic intentions that inspired them. They remain alive among the people even when the official reasons for their creation cease to be relevant; the legitimacy for their creation does not survive, but vernacular religions keep them alive on the margins of hegemonic culture. "[When] some experiences, meanings and values, which cannot be verified or cannot be expressed in terms of the dominant culture, are nevertheless lived and practiced on the basis of the residue - cultural as well as social - of some previous social formation," they tend to linger on as forms of "residual" culture (Williams 1980:40). Similarly, Stuart Hall (2003a:31-32) characterizes creole societies as

\begin{abstract}
translation societies - subject to the "logic" of cultural translation. Translation always bears the traces of the original, but in such a way that the original is impossible to restore. Translation is an important way of thinking about creolization, because it always retains the trace of those elements which resist translation, which remain left-over, so to speak, in lack or excess, and which constantly then return to trouble any effort to achieve total cultural closure. No translation achieves total equivalence, without trace or reminder. ${ }^{29}$
\end{abstract}

That is, even when they suddenly become unauthorized and persecuted, residual cultures or translation societies that had been once part of hegemonic systems tend to persist on the margins as "noise" or "excesses" (often misread by intellectuals as "baroque" [Cara 2002]). Perhaps this is one of the ways, though unexpected and clashing, in which historical circumstances like that of colonialism or nation-state building can hitch marginalized local cultures and communities to the increasingly global forces that have meant to encompass them.

29. This resonates with what Cara (2002) defines as "creole noise" or the opacity of creole folk poetics. 


\section{The Magic and Ritual Power of Transvaluation}

Residual in nature, vernacular creole religions have transformed the meaning and form of dominant religious symbols and gestures in a process best characterized by the concept of "remodeling" developed by linguist Douglas Taylor: "forms are not only reinterpreted, but also gradually changed and transformed to resemble their cultural environment - African words come to seem Portuguese, Portuguese to seem English, English to seem Dutch, and so on" (quoted in Szwed 2003:11). In the Caribbean this has yielded several innovative ways of political, economic, and cultural subsistence predicated on parody and irony, which resonate with the idea of "culture with an attitude." Drawing again from linguistics, Karl Reisman adds the idea of "transvaluation" (quoted in Szwed 2003:11) to the dynamics of "remodeling" and "reinterpretation." 30 This transvaluation of genres explains, for example, the creole "sweet talk" (the use of pretentious English) displayed in "tea meetings" in the West Indies (Abrahams 1983). It characterizes a way of speaking that originally signaled the supremacy of English culture, and by contrast marked the overall disempowerment of creole speakers. It is in this context that "sweet talk" acquired its social power. Creoles having further mastered it, "sweet talk" was transvalued into an alternative yet dependent system of meanings, which now related to their life experiences of empowerment, rather than to the exclusionary intentions of the colonial ruling elites.

This kind of ambiguity, one that subverts from within the imposition of one culture on another, noted by Homi Bhabha (1994), is one of the reasons creolization processes can be seen (following Michel de Certeau's distinction) as a tactic, not a strategy, of subversion. De Certeau (1984:xix) differentiates between strategies and tactics of contestation, arguing that the latter does not imply a plan for a total social change, but rather points to taking advantage of occasional opportunities seized for momentary maneuvers of empowerment: It's "knowing how to get away with things." 31 When Catholic symbols were used illicitly by brujos outside the confines of the Church, they were seized on opportunistically, without changing, or claiming to change the existing power relations of the colony. This was possible by means of the "remodeling" of legitimate Catholic worship, gestures, and symbols, and a

30. Szwed (2003:11) notes that the concept of transvaluation is useful in addressing "the duality of cultural identities, a theme elaborated by Black writers in the Caribbean and the United States (the theme of masking and doubleness in W.E.B. DuBois, Ralph Ellison, and George Lamming) as well as by folklorists (Roger D. Abrahams [1983], on tea meetings in the Anglophonic West Indies; and John Szwed and Morton Marks [1988], on set dances)."

31. Parallel maneuvers in discursive terms are brilliantly illustrated in Cara's (2003) work on the intricacies and poetics of Argentinean criollo talk. 
"transvaluation" of their meanings, marking a "rupture and revenge of signification" (Taussig 1987:5).

When I see brujos taking over the roles of priests and their gestures in their Spiritist and African-based healing and magic rituals - during healing and magic "baptisms," "weddings," and "wakes," or even when baptismal water taken from a church is poured over magic works - I wonder about the powers that had been seized from Catholic worship since colonial times and made to work with other local spirits and entities. The challenge to the very spatial exclusivity and religious hegemony of the Church is double: not only do brujos seize its most central symbols outside its control (as occurs with many other popular Catholic practices), they also combine them and make them speak to Spiritist and African-based spiritual traditions, which were fought against by the Church. Think about the innumerable occasions in which hegemonic Catholic gestures were performed by brujos, drawing their ritual power and then re-channeling them to fit their "heretic" magic purposes - the potency of the original official gestures "stolen with a vengeance," if you will.

If cultural contact and transmission have occurred in the Americas in notso-neighborly contexts (Mintz 1971, Mintz \& Price 1976) within "contact zones" marked by "conditions of coercion, radical inequality, and intractable conflict ... [and] the spatial and temporal copresence of subjects previously separated by geographical and historical disjunctures, and whose trajectories now intersect" (Pratt 1992:6-7), then creolization should be characterized in ways that reflect that basic contention. The more neutral, and in my view misleading, notions of "mixture," "borrowing," or "conversation" among cultures (Hannerz 1987, 1990, 1996) misrepresent the phenomenology of that formative contention. Following its emic inception indexing pollution and contagion - creole and creolization suggest fear of mixtures, fascination with the assumed magic power of exotic others, nightmares of cannibalization, and real and symbolic piracy, plunder, and poaching (Romberg 2001, 2002a, 2002b, 2003b). With such characterization of contact zones, what kinds of cultural alchemy are involved in creolization processes? How can illicit copying transmute into magic potency or ritual piracy?

Scholars, writers, and poets have critically discussed mimicry in relation to the production of alterity and cultural change in colonial situations. ${ }^{32}$ But, as many critics have noted in the context of nation-building ideologies, mimicry as a form of cultural production at the base of creole societies becomes highly problematic when indexing a heroic solution to colonialism, for mimicry suggests passivity and submissive reliance on colonial culture and language. There still remains the question of the ways in which mimicry in the colonial context has been articulated by some postcolonial writers.

32. Memmi 1965, Fanon 1967, Naipaul 1967, Taussig 1993, Bhabha 1994. 
The inherent internal ambiguity recognized by W.E.B. du Bois concerning the "double consciousness" of African Americans under conditions of modernity can be applied also to earlier colonial displays of mimicry and aping, and their social costs. Resonating with du Bois's notion of double consciousness, Alleyne and others suggest that beyond the devaluation of the language of the colonized, the internalization of the colonizers' values created a colonial syndrome that made them see themselves though the eyes of the colonizers, and thereby self-deprecate, and negatively evaluate themselves and their behavior. In line with this defeatist notion, mimicry signals for a number of postcolonial Caribbean intellectuals (such as V.S. Naipaul) the impossibility of colonial subjects ever engaging in a real transformative action from a place that has not already been colonized. For example, in Naipaul's Mimic Men (1967), the main character, Ralph Singh, expresses an inappropriate fascination with traits that he always finds in English women, such as an innate imperial predatory greed that actually scares him and makes him feel inadequate and ashamed (Galloway 1996). ${ }^{33}$ Acknowledging this, Ralph reflects, "it seemed to me that to attach myself to her was to acquire that protection which she offered, to share some of her quality of being marked, a quality which once was mine but which I had lost" (Naipaul 1967:47). ${ }^{34}$

Left at the moment of fascination and terror with the culture of oppressors, mimicry or rather imperfect copies appear as tragic outcomes of colonization, forever entangling any possible authentic expression of identity and real transformation. Always falling short for producing inevitably imperfect copies, the colonized "can never succeed in becoming identified with the colonizer, nor even in copying his role correctly" (Memmi 1965:124). But this ambiguity and impossibility acquire a different meaning within magic, where this imper-

33. Shirley Galloway, 1996, The Mimic Men: A World without a Center, http://www. cyberpat.com/shirlsite/essays/naipaul.html.

34. A similarly inappropriate, demeaning fascination with symbols and gestures of power is vividly expressed in the completely different world of Jerzy Kosinski's The Painted Bird (1965:119) by the young protagonist, a Jewish boy who looks like a Gypsy and manages to escape the Holocaust by hiding in farms. Encountering a German SS officer dressed in full military grab, the boy describes his fascination:

he seemed an example of neat perfection that could not be sullied: the smooth polished skin of his face, the bright golden hair showing under his peaked cap, his pure metal eyes. Every movement of his body seemed propelled by some tremendous internal force. The granite sound of his language was ideally suited to order the death of inferior, forlorn creatures. I was stung by a twinge of envy I had never experienced before, and I admired the glittering death's-head and crossbones that embellished his tall cap. I thought how good it would be to have such a gleaming and hairless skull instead of my Gypsy face which was feared and disliked by decent people. 
fection is constitutive of its technologies and excesses. I take this to be one of the "wicked" sides of the mimicry and magic of imperfect copies.

Within the production of creole religions, mimicry and the production of similes are in fact constitutive of ritual change, and they can be reframed more broadly within processes I characterize as "ritual piracy." One need only follow some of the colonial accounts that trace the elaborate religious/state rituals that were performed every time a plantation was inaugurated, a city founded, or a chapel consecrated, where the priest together with colonial officials publicly asserted the colonial social order through the power of religious symbols, or the symbols of religious and state power. Essential to the dynamics of ritual change under colonialism, the creation of vernacular forms of religious practice depended on the de facto imposed recognition of powerful others and the appropriation of their symbols (Taussig 1987, 1993, 1997; Stoller 1995, 1997). The Catholicism found in Vodou, Candomblé, and Santeria was not just an ecumenical screen meant to hide the worship of African deities from official persecution, as some syncretism scholars have suggested. Rather, it was the religion of the colonizers: revised, transformed, and appropriated by the oppressed folk to harness its power within their universes of discourse. In this way, argues Andrew Apter (1991:254), slaves took possession of Catholicism, thereby repossessing themselves as active spiritual subjects.

Jean and John Comaroff (1993) remind us that the signs and techniques that are incorporated in ritual often come to be potent precisely because of the historical circumstances in which they acquire their meanings. During Catholic rule, Catholic symbols were forced upon the colonies and called on to legitimize the colonial order as a whole. Yet only certain symbols and gestures were adopted as potent transcendental forces within vernacular religious practices, and only these were emulated, though not without severe opposition and punishment from ecclesiastical agents, attempting to protect their exclusive ownership. For example, miraculous appearances, first institutionalized by the Church and forming the basis for the creation of colonial chapels and towns, were soon freed from its dominion, mushrooming in the countryside and popular imagination and worship. Religious images, originally meant to be worshiped within chapels, were adopted, changed, and worshipped in private altars (and later brought together with Spiritist entities and African deities) away from the centers of religious power (Romberg 2003c). In a similar vein, Roger Bastide (1978:278) interprets the effect of popular Catholicism on slaves, who were exposed to

the ex votos testifying to miracles performed by the Virgin or the saints in response to desperate prayers and promises, making them recognize that the whites were masters of benign or formidable powers. Some connection may have formed in [their] unconscious mind[s] between the stronger mana 
of the Catholic religion and the whites' higher place on the social ladder. This explains why [they] grafted the Catholic tradition onto [their] own"35

Indeed, at different conjunctures in Puerto Rican history vernacular healers who assimilated the prevailing religious symbols of the state or the ruling elites were persecuted as heretics during the first three centuries of Catholic colonial rule and as charlatans during the state-building process of the first half of the twentieth century - a situation that would change drastically after the 1980s (Romberg 1998, 2003a, 2003c). But more importantly, following de Certeau (1984:xiii), vernacular religious practitioners often subverted oppressive religious laws and representations of the Catholic Church "not by rejecting or altering them, but by using them with respect to ends and references foreign to the system they had no choice but to accept." Indeed, Bolland (1997:20) finds that infiltrating metropolitan cultures with creole innovations is what best characterizes the idea of creolization. Indeed, brujos have been doing just that: smuggling their own agendas into metropolitan culture.

Even today at the Brazilian Church of Bomfim in Bahia, followers of the Afro-Brazilian Candomblé still celebrate their orisha Oshalá (Oxala), Bastide (1978:276) notes, at the yearly "washing of the steps" festival. ${ }^{36}$ This ritual commemorates the promise a Portuguese soldier made to Jesus before he went off to war during colonial times. He pledged that if he came back unhurt he would wash the atrium of the church. For Candomble practitioners it is "a doublet of the ritual for purifying the divine stones" representing the orishas (deities) with "the water of Oxalá" (Oxalá being the Candomblé counterpart of Jesus), a yearly ritual that is meant to renew their ashé or power. ${ }^{37}$

As these examples show, more than elucidating cultural transmission under situations of displacement and de-territorialization, creolization suggests the unplanned and unfriendly symbolic takeover of hegemonic symbols of powerful others in situations of physical invasion and conquest. Appalling as slavery and many other dreadful situations of involuntarily human "contact" have been, the mimetic and homeopathic faculties of magic have pro-

35. I purposely omitted the end of this quote where Bastide reiterates the sociological categorical differentiation he makes throughout this work between (Catholic) religion and (African) magic (my emphasis) not because it is meaningless but because such a discussion exceeds the purpose of this essay.

36. For an excellent, updated version of the ritual of the washing of the steps at the Church of Bomfim that traces its recent commodification and politicization, see Silverstein (1995). 37. Another form of "reinterpretation" mentioned by Bastide refers to the ritual use of the small bell used during Catholic Mass at the moment of the consecration of the Host. Practitioners of Candomblé in Recife use it instead of the African adjá bell to call the attention of the congregation "to the praising of Orixálá, the greatest of the orixás" and thereby summon the other orixás as well (Bastide 1978: 276). A commercial bell is also used in Puerto Rican espiritismo and brujería practices to mark and announce the presence of spirits (Romberg 2003c). 
vided a complex source of realistic empowerment, which I propose in revisiting the idea of creolization.

Magic, James Frazer (1960) noted more than a century ago, is about producing copies or for taking significant parts to stand for the whole, according to the sympathetic (similarity) and homeopathic (contact or contagion) principles, respectively. Following the law of similarity, the copy, in magic practice, affects the original to such a degree that the representation shares or acquires the properties of the represented (Taussig 1997:48-49). Here I link the mimetic faculty of magic to symbolic piracy; that is, the strategic, unauthorized appropriation of symbols of power, religious or civil, which become empowering against their initial purpose. Magical mimesis on the colonial frontier (Taussig 1993:59) points to a basic empowering effect of the imitation function, either through the production of similes by mimicry or by contiguity and contact, by which a copy partakes of the power of the original. ${ }^{38}$ The technologies of magic illustrate that copies, even if imperfect, enable a transmutation of meanings; similes draw on the power of the original and transmute it to the copy. ${ }^{39}$

Imagine the praying of Hail Marys and Our Fathers in litany by brujos and their clients during the performance of a "black" magic work (the result of an assembly of various African-based creole practices) meant to symbolically kill (i.e., neutralize) wrongdoers, and the subsequent offerings of novenas for their proper departure from this world, or the exorcising of an evil spirit "lodging" in the body of an unfortunate victim, then helping raise the thus-exorcised spirit to a higher level of existence. Haydée defined herself as an espiritista bruja (Spiritist witch-healer) and was extremely well versed in Catholic and Protestant worship ${ }^{40}$ as well as in African-based healing and magic (Romberg 2003c). On one occasion, Haydée fashioned, out of a cardboard box emptied of its bar of soap, a "coffin" (complete with cottonballs padding its interior) in which to "bury" her client's enemy (a small lizard serving as the surrogate corpse, in this case) - who, divination revealed, had caused the client all kinds of serious misfortunes, ending in a stroke that had left her half-paralyzed. This was the imperfect copy of a "real" wake (performed in the presence of an imperfect copy of a funerary coffin) which

38. Grey Gundaker (1998) identifies the imitation of signs of African divination systems as an alternative mode of literacy in the African diaspora.

39. The magical power of mimesis had been essential in European medieval popular forms of Catholicism. The idea that spiritual power can be attained by mimesis, or imitation, of God follows a long tradition initiated in the Gospels and codified in De Imitatione Christi (The Imitation of Christ), the set of fifteenth-century Christian devotional books attributed to Thomas à Kempis (1380-1471). Influential ever since, it proposes the emulation of the life of Christ as a way to achieve a personal, direct spiritual unity with Christ. 40. Born into a Catholic family, her father was an espiritista; her mother converted to Protestantism after the American invasion, as did many Puerto Ricans. 
was intended, just as in an actual wake, to help the soul of the wicked enemy depart peacefully to the "celestial mansions" by means of the power invested in Hail Marys and Our Fathers. Isn't this an uncanny use of such prayers? ${ }^{41}$

\section{Mimicry, Pollution, And the Threat of Imperfect Copies}

More than likely, it was this recurrent and uncontrollable creation of copies, of Catholic worship, speech, dress, leisure, and exchange, that opened the cultural Pandora's box of gate-keeping nightmares and irreverent usurpations at different periods of Puerto Rican history. The numerous regulations that were created in Caribbean colonial and postemancipation societies to prevent such unauthorized acts of mirroring happening have been shown to have been the response to essential if often subtle wars of entitlements over gestures, dress, and language (Burton 1997, Brereton \& Yelvington 1999). As Bhabha (1994:88) says in regard to colonial mimicry, the menace of mimicry is its "double vision," which in disclosing the ambivalence of colonial discourse also disrupts its authority. Authoritative discourses need to be singular and hegemonic; by their "very nature incapable of being doublevoiced, [they] cannot enter into hybrid constructions" (Bakhtin 1981:344). Taking the symbols of Catholicism away from the cathedrals and making them speak in ermitas was indeed a threat to the exclusivity imposed by the colonial religious and civil authorities (Romberg 2003c:29-53). Even when unwilling slaves and peasants were made to follow Catholic rituals by force, their attempt to comply with this imposition could only be regarded within the colonial context as inappropriate, not ever quite the right gesture, only the result of submissive, ignorant aping.

But there is an added component to the "game of mirroring" (Bhabha 1994:85-92). What may have looked from the outside as successive acts of submission or incompetent mimicry may well have been tropes of cannibalization or consumption through the imitation of symbols, or the substitution

41. The early colonists, most of whom came from Andalusia and later the Canary Islands, were from the lower and marginalized classes. These colonists settled in isolated areas and engaged in subsistence agriculture and trading in contraband with nearby islands and passing pirate vessels (see Caro Costas 1983). They practiced a popular form of medieval Mediterranean Catholicism common to various sixteenth-century European societies. In Puerto Rico, however, this form of popular Catholicism continued to flourish with little control by the official Church (Vidal 1994:13). Some aspects of the history of Puerto Rican popular devotions in the eighteenth century are well documented in López Cantos (1992) and Vidal (1986). For a current representation of these popular devotions, see the catalogue of the exhibition on popular religion in Puerto Rico curated by Alegría-Pons (1988), and the volume edited by Quintero Rivera (1998). 
of parts that stand for powerful others, not at all foreign to the technologies of magic, as noted earlier. Maybe it was against the fear of being cannibalized (at least symbolically) that the colonial ruling elites reacted so defensively by ridiculing those free colored Creoles who they saw "aping" them (see Bastide 1978, for Brazil and Dayan 1995, for Saint-Domingue). This menace of mirroring is evident also in Price's (1998:171-72) report on the folklore surrounding the imprisonment of Médard:

that enigmatic, silent sculptor who died a decade ago, was sent to the French Guiana prison camps for having made a perfect "photo" (a sculpture in wood) of Colonel de Coppens ... [Absolutely everyone] knows that Médard once saw Coppens, that he fashioned his image in wood with every detail, from facial expression to military medals, exactly in place, and that he was condemned to the prison camps for this act of gross impertinence.

Those who persecuted witches in colonial times "knew" that magic worked through copies, even imperfect ones. Catholic worship was all about the spiritual power emanating from the transmutation of the physical into the spiritual realm. Thus it was imperative for the Church to keep the transcendental realm in official hands as a matter of survival for the whole colonial order. Several edicts in Puerto Rico prohibited the invocation of Catholic saints, and any material embellishments added to them, outside the church. Throughout roughly three centuries, the Inquisition and numerous ecclesiastical and government decrees sought to restrict the practices of individuals ("heretics") who had "illegally" mimicked the gestures of the Church and thus been accused of appropriating the management of "the sacred" outside the Church. The Church allowed only priests to perform and supervise healing procedures (leading to spiritual cures) which were then carefully circumscribed in a series of laws. Specific techniques and rituals that involved the invocation of supernatural powers were described in Constitution CXV (1645), in accordance with the Council of Trent (1545-63). Constitution CXV prohibited the exhibition of "nóminas" (amulets listing the names of saints), the use of "ensalmos" (magic spells), and the use of objects of superstition (e.g., "unknown characters," "divination systems") unless first seen and approved by the Church (Huerga 1989:132). Since Church officials performed ensalmos and nóminas as part their regular practices, Constitution CLVII gave full authority to local Church officials to police the performance of these among nonecclesiastical practitioners, asking the authorities to determine ad hoc which instances were to be punished as superstition, sorcery, bewitchment, divination, or spell-induced enchantment (Murga \& Huerga 1989:480).

Ironically, by virtue of the very system of imitation that had been in place in accordance with the Church's own devotional teachings, the gates to the realm of miraculous occurrences had been opened wide to an eagerly devout 
public ever since the earliest days of colonization. Indeed, the possibilities of vernacular reworkings of the ideology of sacred mimesis, which promoted the imitation of the life of Jesus, had become unlimited. Many of the faithful, following the official stories heard in their churches, claimed to have had miraculous experiences, some in the form of apparitions, others in the form of wondrous encounters with sacred artifacts, which then often became the objects of popular devotion, outside the confines and control of the Church. With the aim to restrict the creation and propagation of unauthorized religious images and artifacts, Constitution CIX reserved to the Church alone the right to certify miracles and to incorporate into its liturgy new holy relics (Murga \& Huerga 1989:437).

Despite the prohibitions of the Church, individuals who believed strongly in the stories of the Church persisted in claiming to have experienced their own private miracles, wrought by prayer before the statue or picture of a saint, which then would eventually become the subject of public veneration. Such was the case of Francisca Lares, a woman from the village of Moca. On July 4, 1865, she was accused by the parish priest of claiming that her carved-stone image of Nuestra Señora del Rosario had "grown and developed miraculously" through time. Amazingly, her case instigated a huge revolt, fueling the exchange of official letters (through the rest of July and August of that year) between the mayor, the parish priest of La Moca, the bishop, and the civil governor of the island, at the end of which her miraculous image was confiscated (no more details were recorded) by the parish priest. ${ }^{42}$

\section{Creolization with an Attitude}

Imitating the symbols and gestures of powerful others "with an attitude" is probably the closest characterization of the phenomenology of creolization, as specified here. It certainly does not exude heroism. In my research on Puerto Rican brujería I have found that at different historical circumstances brujos have appropriated religious, intellectual, bureaucratic, and commercial symbols of power. It was in light of colonial religious and cultural hegemonic gate-keeping practices that the "irreverent" appropriation of Catholic signs and gestures by Creole brujos acquired their transcendental empowerment. These techniques of adaptation and relative empowerment - which characterize the tactics or "the art of the weak" (de Certeau 1984:37) - ethereal as they might seem, draw their particular sociological significance from the

42. San Juan, Puerto Rico, Archivo General de Puerto Rico, 1865, Fondo Gobernadores Españoles, Box 283. Documents about a woman in Moca. Letters exchanged between the Bishop, parish priest, and governor about a miraculous figure followed by prosecution of owner. 
specific configurations of power that gave rise to them in the first place. In this sense, they provide a "diagnostic of power" rather than a romantic view of resistance (Abu-Lughod 1990:42). ${ }^{43}$ In fact, ritual piracy was undoubtedly not the sole example of "wicked" forms of partnership between centers of hegemonic power and their margins. Mutual dependency and ambiguity have inspired other parasitic relationships in the Caribbean since colonization, which, in the context of an inherent phenomenology of scarcity, made the recognition of powerful others and the imitation of their symbols essential to the dynamics of ritual change under colonialism (see Lionnet 1992; Taussig 1993, 1997; Stoller 1995, 1997). After all, "the space of a tactic is the space of the other" (de Certeau 1984:37).

Especially intriguing is the social price paid by white and colored Creoles alike for being like "but not quite" (Bhabha 1994:86). In colonial situations of cultural contact under conditions of scarcity, this social price needed to be kept as a public secret. What kinds of power might be derived, and released, from this form of "defacement" (Taussig 1999)? From the parody and tragedy that result when open discussion of a "public secret" is precluded? The power released from refracting mirrors, in which the object of desire gets further blurred as it is reflected back through a host of images in a chamber of mirrors, is presented here as an alternative to various metaphors of mixture suggested for creolization, such as dialogue, negotiation, and hybridity. Broadly, ritual piracy, far from being a "relatively safe counterhegemonic revision of the way we understand culture, power, and culture change" (Khan 2001:272), suggests the plundering of cultures as itself a form of cultural production. And yet this cultural pirating has been offered as an unquestionably nonheroic but nonetheless empowering form of tactically "wicked" partnership between centers of hegemonic power and their margins, the goal of which can be characterized more as "partaking of" rather than "resistance to" dominant culture. Pragmatically drawing upon the advantages of its coterminous networks of power, "ritual piracy" paradoxically begets, if unintentionally, its incorporation into the margins rather than its erasure.

43. I thank one of the anonymous reviewers for pressing me to redress the kind of power that is implied by "ritual piracy" in light of Abu-Lughod (1990). 


\section{REFERENCES}

Abrahams, Roger D., 1983. The Man of Words in the West Indies: Performance and the Emergence of Creole Culture. Baltimore MD: Johns Hopkins University Press.

-, 2002. Criolian Contagion. Caribbean Speaker Series, Swarthmore College, Swarthmore PA.

-, 2003. Questions of Criolian Contagion. Journal of American Folklore 116(459):7387.

- \& JoHN F. SzWED (eds.), 1983. After Africa: Extracts from British Travel Accounts and Journals of the Seventeenth, Eighteenth, and Nineteenth Centuries Concerning the Slaves, their Manners, and Customs in the British West Indies. New Haven CT: Yale University Press.

Abu-Lughod, Lila, 1990. The Romance of Resistance: Tracing Transformations of Power Through Bedouin Women. American Ethnologist 17:41-55.

Alegría-Pons, José Francisco, 1988. Aspectos de la religiosidad popular en Puerto Rico. Exhibition catalogue. San Juan: Centro de Estudios Avanzados de Puerto Rico y el Caribe. Appeared also in La Revista del Centro de Estudios Avanzados de Puerto Rico y el Caribe 7:105-9.

Allen, Carolyn, 2002. Creole: The Problem of Definition. In Verene A. Shepherd \& Glen L. Richards (eds.), Questioning Creole: Creolisation Discourses in Caribbean Culture: In Honour of Kamau Brathwaite. Kingston: Ian Randle; Oxford: James Curry, pp. 47-63.

Alleyne, Mervyn C., 1985. A Linguistic Perspective on the Caribbean. In Sidney W. Mintz \& Sally Price (eds.), Caribbean Contours. Baltimore MD: Johns Hopkins University Press.

APTER, ANDREw, 1991. Herskovits's Heritage: Rethinking Syncretism in the African Diaspora. Diaspora 1(3):235-60.

Bakhtin, Mikhail M., 1981. The Dialogic Imagination: Four Essays. Austin: University of Texas Press.

Balutansky, Kathleen M. \& Marie-Agnès Sourieau (eds.), 1998. Caribbean Creolization: Reflections on the Cultural Dynamics of Language, Literature, and Identity. Gainesville: University Press of Florida.

Baron, Robert, 2003. Amalgams and Mosaics, Syncretisms and Reinterpretations: Reading Herskovits and Contemporary Creolists for Metaphors of Creolization. Journal of American Folklore 116(459):88-115.

Bastide, Roger, 1978. The African Religions of Brazil: Toward a Sociology of the Interpenetration of Civilizations. Baltimore MD: Johns Hopkins University Press.

Benítez-Rojo, Antonio, 1992. The Repeating Island: The Caribbean and the Postmodern Perspective. Durham NC: Duke University Press. 
Bernabé, Jean, Patrick Chamoiseau \& Raphä̈l Confiant, 1989. Eloge de la Créolitél In Praise of Creolness. Paris: Gallimard.

Bнавна, Номі K., 1994. Of Mimicry and Man: The Ambivalence of Colonial Discourse. London: Routledge.

Bolland, O. Nigel, 1992. Creolization and Creole Societies: A Cultural Nationalist View of Caribbean Social History. In Alistair Hennessy (ed.), Intellectuals in the TwentiethCentury Caribbean, Vol.1: Spectre of the New Class: The Commonwealth Caribbean. London: Macmillan Caribbean, pp. 50-79.

-, 1997. Struggles for Freedom: Essays on Slavery, Colonialism and Culture in the Caribbean and Central America. Belize City: Angelus Press; Kingston: Ian Randle.

Bourdieu, Pierre, 1990. The Logic of Practice. Stanford CA: Stanford University Press. [Orig. 1980.]

Brandon, George, 1993. Santeria from Africa to the New World: The Dead Sell Memories. Bloomington: Indiana University Press.

Brathwatte, EDWARD, 1971. The Development of Creole Society in Jamaica 1770-1820. Oxford: Clarendon.

Brereton, Bridget \& Kevin A. Yelvington (eds.), 1999. The Colonial Caribbean in Transition: Essays in Postemancipation Social and Cultural History. Kingston: The Press University of the West Indies; Gainesville: University Press of Florida.

Brown, David H., 2003. Santeria Enthroned: Art, Ritual, and Innovation in an AfroCuban Religion. Chicago: University of Chicago Press.

Browne, Katherine E., 2004. Creole Economics: Caribbean Cunning Under the French Flag. Austin: University of Texas Press.

Burton, Richard D.E., 1997. Afro-Creole: Power, Opposition, and Play in the Caribbean. Ithaca NY: Cornell University Press.

CABRERA, Lydia, 1975. El Monte: Igbo, finda, ewe orisha, vititi nfinda: Notas sobre las religiones, la magia, las supersticiones y el folklore de los negros criollos y el pueblo de Cuba. Miami: Ediciones Universal. [Orig. 1954.]

CANTwell, Robert, 1993. Ethnomimesis: Folklore and the Representation of Culture. Chapel Hill: University of North Carolina Press.

CARa, Ana. C., 2002. Creole Noise vs. Baroque Excesses. Unpubl. paper, Voice/Over: Cultural Transmission as Translation, Exchange, and Reproduction. A symposium in honor of Roger D. Abrahams, University of Pennsylvania, Philadelphia.

-, 2003. The Poetics of Creole Talk: Toward an Aesthetic of Argentine Verbal Art. Journal of American Folklore 116(459):36-56.

Caro Costas, Aida R., 1983. The Organization of an Institutional and Social Life. In Arturo Morales Carrión (ed.), Puerto Rico: A Political and Cultural History. New York: W.W. Norton, pp. 25-40. 
Certeau, Michel de, 1984. The Practice of Everyday Life. Berkeley: University of California Press.

Chambers, IAIN, 1994. Migrancy, Culture, Identity. London: Routledge.

Chaudenson, Robert, 2001. Creolization of Language and Culture. London: Routledge. [Orig. 1992.]

Comaroff, Jean \& John Comaroff (eds.), 1993. Modernity and its Malcontents. Chicago: University of Chicago Press.

Condé, Maryse, 1999. On the Apparent Carnivalization of Literature from the French Caribbean. In Jean Muteba Rahier (ed.), Representations of Blackness and the Performance of Identities. Westport CT: Bergin \& Garvey, pp. 91-97.

- \& Madeleine Cottenet-Hage (eds.), 1995. Penser la créolité. Paris: Éditions Karthala.

Dayan, Joan, 1995. Haiti, History and the Gods. Berkeley: University of California Press.

Desmangles, Leslie G., 1992. The Faces of the Gods: Vodou and Roman Catholicism in Haiti. Chapel Hill: University of North Carolina Press.

Douglas, Mary, 1966. Purity and Danger: An Analysis of the Concepts of Pollution and Taboo. London: Routledge.

Droogers, André, 1989. Syncretism: The Problem of Definition, the Definition of the Problem. In Jerald Gort, Hendrik Vroom, Rein Fernhout \& Anton Wessels (eds.), Dialogue and Syncretism: An Interdisciplinary Approach. Grand Rapids, MI: Eerdmans; Amsterdam: Rodopi, pp. 7-25.

DRummond, LeE, 1980. The Cultural Continuum: A Theory of Intersystems. Man 15:35274.

DuAny, Jorge, 1985. Ethnicity in the Spanish Caribbean: Notes on the Consolidation of Creole Identity in Cuba and Puerto Rico, 1762-1868. Ethnic Groups 6:93-123.

-, 1998. La religiosidad popular en Puerto Rico: Una perspectiva antropológica. In Angel Quintero Rivera (ed.), Vírgenes, magos y escapularios: Imaginería, etnicidad y religiosidad popular en Puerto Rico. Río Piedras: Centro de Investigaciones Sociales de la Universidad de Puerto Rico, Centro de Investigaciones Académicas de la Universidad del Sagrado Corazón and Fundación Puertorriqueñas de las Humanidades.

ENwezor, OKwUl et al., (eds.). 2003. Documenta 11_Platform3: Créolité and Creolization. Ostfildern, Germany: Hatje Cantz Verlag.

Fabian, Johannes, 2001. Anthropology with an Attitude: Critical Essays. Stanford CA: Stanford University Press.

FAnON, FrantZ, 1967. Black Skin, White Masks. New York: Grove Press. [Orig. 1952.] 
Fernández Olmos, Margarite \& Lizabeth Paravisini-Gebert (eds.), 2003. Creole Religions of the Caribbean: An Introduction from Vodou and Santería to Obeah and Espiritismo. New York: New York University Press.

Frazer, James George, 1960. The Golden Bough: A Study in Magic and Religion. New York: Macmillan. [Orig. 1901.]

Glissant, Edouard, 1997. Poetics of Relation. Ann Arbor: University of Michigan Press. [Orig. 1990.]

Gort, Jerald, Hendrik Vroom, Rein Fernhout \& Anton Wessels (eds.), 1989. Dialogue and Syncretism: An Interdisciplinary Approach. Grand Rapids, MI: Eerdmans; Amsterdam: Rodopi.

Grosfoguel, Ramón, Frances Negrón-Muntaner \& Chloe S. Georas, 1997. Beyond Nationalist and Colonialist Discourses: The Jaiba Politics of the Puerto Rican EthnoNation. In Frances Negrón-Muntaner \& Ramón Grosfoguel (eds.), Puerto Rican Jam: Rethinking Colonialism and Nationalism. Minneapolis: University of Minnesota Press, pp. 1-38.

Gundaker, Grey, 1998. Signs of Diaspora, Diaspora of Signs. New York: Oxford University Press.

Hall, Stuart (ed.), 1997. Representation: Cultural Representations and Signifying Practices. London: Sage.

-, 2003a. Créolité and the Process of Creolization. In Okwui Enwezor et al. (eds.), Documenta 11_Platform3: Créolité and Creolization. Ostfildern, Germany: Hatje Cantz Verlag, pp. 27-41.

-, 2003b. Creolization, Diaspora, and Hybridity in the Context of Globalization. In Okwui Enwezor et al. (eds.), Documenta 11_Platform3: Créolité and Creolization. Ostfildern, Germany: Hatje Cantz Verlag, pp.185-98.

HanNERZ, Ulf, 1987. “The World after Creolization.” Africa 57:546-59.

-, 1990. Cosmopolitans and Locals in World Culture. In Mike Featherstone (ed.), Global Culture, Nationalism, Globalization and Modernity. London: Routledge, pp. 237-51.

-, 1996. Transnational Connections: Culture, People, Places. London: Routledge.

HARING, LEE, 2003. Techniques of Creolization. Journal of American Folklore 116(459):1935.

Harney, Stefano, 1996. Nationalism and Identity: Culture and the Imagination in a Caribbean Diaspora. Atlantic Highlands NJ: Zed Books; Kingston: The Press University of the West Indies.

Herskovits, Melville, J. 1937. African Gods and Catholic Saints in New World Negro Belief. American Anthropologist 39(4, pt. 1):635-43.

-, 1958. Acculturation: The Study of Culture Contact. Gloucester MA: P. Smith. [Orig. 1938.] 
Hintzen, Percy, 2002. Race and Creole Ethnicity in the Caribbean. In Verene A. Shepherd \& Glen L. Richards (eds.), Questioning Creole: Creolisation Discourses in Caribbean Culture: In Honour of Kamau Brathwaite. Kingston: Ian Randle; Oxford: James Curry, pp. 92-110.

Huerga, Álvaro (comp.), 1989. Damián López de Haro: Constituciones Sinodales de Puerto Rico 1645. Ponce: Universidad Católica de Puerto Rico.

KHAN, Aisha, 2001. Journey to the Center of the Earth: The Caribbean as Master Symbol. Cultural Anthropology 16:271-302.

Kosinski, Jerzy, 1965. The Painted Bird. London: Bantam Books.

KUTZINSKI, Vera M., 1993. Sugar's Secrets: Race and the Erotics of Cuban Nationalism. Charlottesville: University Press of Virginia.

Lionnet, FrançoIse, 1992. Logiques Métisses: Cultural Appropriation and Postcolonial Representations. College Literature 19-20:100-20.

Livingston, Paisley, 1992. Models of Desire, René Girard and the Psychology of Mimesis. Baltimore MD: Johns Hopkins University Press.

López Cantos, Ángel, 1992. La religiosidad popular en Puerto Rico (siglo XVIII). Santurce, Puerto Rico: Centro de Estudios Avanzados de Puerto Rico y el Caribe.

López VAldÉs, RAFAel L., 1985. Componentes africanos en el etnos cubano. Havana: Editorial de Ciencias Sociales.

Lovejoy, Paul E. \& David V. Trotman, 2002. Enslaved Africans and their Expectations of Slave Life in the Americas: Towards a Reconsideration of Models of "Creolisation." In Verena A. Shepherd \& Glen L. Richards (eds.), Questioning Creole: Creolisation Discourses in Caribbean Culture: In Honour of Kamau Brathwaite. Kingston: Ian Randle; Oxford: James Curry, pp. 67-91.

Memmi, Albert, 1965. The Colonizer and the Colonized. Boston MA: Beacon Press.

MintZ, Sidney W., 1971. The Socio-Historical Background to Pidginization and Creolization. In Dell Hymes (ed.), Pidginization and Creolization of Languages: Proceedings of a Conference Held at the University of the West Indies Mona, Jamaica, April 1968. Cambridge: Cambridge University Press, pp. 481-96.

-, 1974. Caribbean Transformations. New York: Columbia University Press.

,- 1985 . From Plantations to Peasantries in the Caribbean. In Sidney W. Mintz \& Sally Price (eds.), Caribbean Contours. Baltimore MD: Johns Hopkins University Press, pp. 127-53.

Mintz, Sidney W. \& Richard Price, 1976. An Anthropological Approach to the AfroAmerican Past: A Caribbean Perspective. Philadelphia PA: Institute for the Study of Human Issues.

Moore, Robin, 1997. Nationalizing Blackness : Afrocubanismo and Artistic Revolution in Havana, 1920-1940. Pittsburgh PA: University of Pittsburgh Press. 
Murga, Vicente \& Álvaro Huerga (comp.), 1989. Episcopologio de Puerto Rico III de Francisco de Cabrera a Francisco de Padilla (1611-1695). Ponce, Puerto Rico: Universidad Católica de Puerto Rico.

NaIPAUL, V.S., 1967. The Mimic Men. London: Penguin.

NetTleford, Rex M., 1970. Mirror Mirror: Identity, Race and Protest in Jamaica. Kingston: William Collins and Sangster.

OlWIG, KAREN Fog, 1993. Global Culture, Island Identity: Continuity and Change in the Afro-Caribbean Community of Nevis. Chur, Switzerland: Harwood Academic Publishers.

OrTiz, Fernando, 1995. Cuban Counterpoint: Tobacco and Sugar. Durham NC: Duke University Press. [Orig. 1947.]

Pratt, Mary Louise, 1992. Imperial Eyes: Travel Writing and Transculturation. London: Routledge.

Price, Richard, 1996. Maroon Societies: Rebel Slave Communities in the Americas. Baltimore MD: Johns Hopkins University Press. [Orig. 1973.]

,- 1998. The Convict and the Colonel. Boston MA: Beacon Press.

-, 2001. The Miracle of Creolization: A Retrospective. New West Indian Guide 75:3564.

-, (forthcoming). The Concept of Creolization. In David Eltis \& Stanley L. Engerman (eds.), World History of Slavery. Cambridge: Cambridge University Press.

— \& SAlly PRICE, 1997. Shadowboxing in the Mangrove. Cultural Anthropology 12:336.

QUINTERO RIVERA (ed.), 1998. Vírgenes, magos y escapularios: Imaginería, etnicidad y religiosidad popular en Puerto Rico. San Juan: Centro de Investigaciones Sociales de la Universidad de Puerto Rico, Centro de Investigaciones Académicas de la Universidad del Sagrado Corazón, and Fundación Puertorriqueñas de las Humanidades.

Rhys, Jean, 1966. Wide Sargasso Sea. London: Penguin Books.

Román, Reinaldo Luis, 2000. Conjuring Progress and Divinity: Religion and Conflict in Cuba and Puerto Rico, 1899-1956. Ph.D. dissertation, University of California at Los Angeles.

Romberg, Raquel, 1998. Whose Spirits are They? The Political Economy of Syncretism and Authenticity. Journal of Folklore Research 35:69-82.

-, 2001. Symbolic Piracy: Puerto Rican Brujería from Heresy to Entrepreneurship. Unpubl. paper, "Take/Cover," Center for Folklore and Ethnography, University of Pennsylvania, Philadelphia.

-, 2002a. Revisiting Creolization. Unpubl. paper, Voice/Over: Cultural Transmission as Translation, Exchange, and Reproduction. A symposium in honor of Roger D. Abrahams, University of Pennsylvania, Philadelphia. 
-. 2002b. Symbolic Piracy: Creolization with a Twist. Unpubl. paper, American Folklore Society, Rochester NY.

-. 2003a. From Charlatans to Saviors: Espiritistas, Curanderos, and Brujos Inscribed in Discourses of Progress and Heritage. Centro Journal 15:146-73.

-, 2003b. The Magic of Ritual Piracy: Creolization with a Twist? Unpubl. paper, Caribbean Studies Association, Belize City, Belize.

-, 2003c. Witchcraft and Welfare: Spiritual Capital and the Business of Magic in Modern Puerto Rico. Austin: University of Texas Press.

Roseberry, William, 1989. Balinese Cockfights and the Seduction of Anthropology. In William Roseberry, Anthropologies and Histories: Essays in Culture, History, and Political Economy. New Brunswick NJ: Rutgers University Press, pp. 17-29.

Schwartz, Henry \& Sangeeta Ray (eds.), 2000. A Companion to Postcolonial Studies. Maldemn MA: Blackwell Publishers.

Scott, David, 1991. That Event, This Memory: Notes on the Anthropology of African Diasporas in the New World. Diaspora 1:261-84.

ShePherd, Verene A. \& GLen L. Richards (eds.), 2002. Questioning Creole: Creolisation Discourses in Caribbean Culture: In Honour of Kamau Brathwaite. Kingston: Ian Randle; Oxford: James Curry.

SiLverstein, Leni, 1995. The Celebration of Our Lord of the Good End: Changing State, Church, and Afro-Brazilian Relations in Bahia. In David J. Hess \& Roberto A. DaMatta (eds.), The Brazilian Puzzle: Culture on the Borderlands of the Western World. New York: Columbia University Press, pp. 134-57.

Smith, Michael Garfield, 1965. The Plural Society in the British West Indies. Berkeley: University of California Press.

SpitZer, Nicholas R., 2003. Monde Créole: The Cultural World of French Louisiana Creoles and the Creolization of World Cultures. Journal of American Folklore 116(459):5772.

Stoller, Paul, 1995. Embodying Colonial Memories: Spirit Possession, Power, and the Hauka in West Africa. New York: Routledge.

—, 1997. Sensuous Scholarship. Philadelphia: University of Pennsylvania Press.

Szwed, JoHn F., 2003. Metaphors of Incommensurability. Journal of American Folklore 116(453):9-18.

Taussig, Michael, 1987. Shamanism and Colonialism and the Wild Man: A Study of Terror and Healing. Chicago: The University of Chicago Press.

-, 1993. Mimesis and Alterity, A Particular History of the Senses. New York: Routledge.

-, 1997. Magic of the State. New York: Routledge. 
-, 1999. Defacement: Public Secrecy and the Labor of the Negative. Stanford CA: Stanford University Press.

Trouillot, Michel-Rolph, 1982. Motion in the System: Coffee, Color, and Slavery in Eighteenth-Century Saint-Domingue. Review 3:331-88.

-, 1992. The Caribbean Region: An Open Frontier in Anthropological Theory. Annual Review of Anthropology 21:19-42.

-, 1995. Silencing the Past: Power and the Production of History. Boston MA: Beacon Press.

- 1998. Culture on the Edges: Creolization in the Plantation Context. Plantation Society in the Americas 5:8-28.

Vidal, Jaime R., 1994. Citizens Yet Strangers: The Puerto Rican Experience. In Jay P. Dolan \& Jaime R. Vidal (eds.), Puerto Rican and Cuban Catholics in the U.S., 19001965. Notre Dame, IN.: University of Notre Dame Press, pp. 10-143.

Vidal, TeOdoro, 1986. San Blas en la tradición puertorriqueña. San Juan: Ediciones Alba.

-, 1989. Tradiciones en la brujería puertorriqueña. San Juan: Ediciones Alba.

Williams, Raymond, 1980. Base and Superstructure in Marxist Theory. In Raymond Williams, Problems in Materialism: Selected Essays. London: Verso, pp. 31-49.

Yelvington, Kevin, 2001. The Anthropology of Afro-Latin America and Caribbean: Diasporic Dimensions. Annual Review of Anthropology 30:227-60.

Young, Robert J.C., 1995. Colonial Desire: Hybridity in Theory, Culture and Race. London: Routledge.

RAQUEL ROMBERG

Department of Anthropology

Temple University

Philadelphia PA 19122, U.S.A.

<rromberg@temple.edu> 